\title{
Budżet obywatelski jako instrument partycypacji spolecznej w obszarze kultury
}

\section{Abstract \\ Participatory Budget as an Instrument of Social Participation in the Culture Sector}

For the last decades, public management has recorded a dynamic growth, which is manifested by the concepts of new public management and public governance. As part of these concepts, there emerge tools to support the process of public sector management, including a participatory budget a tool that allows local communities to decide on the allocation of budget resources in their local government units. The aim of the paper is to try to answer the question of whether the participatory budget is an effective instrument of social participation in the culture sector. In order to investigate this issue, the author describes the idea of participatory budget and presents the analysis results on how this tool is applied in public management in the capital cities of 18 Polish provinces. The results show that that the participatory budget is rarely used to its fullest potential.

Keywords: participatory budget, social participation, culture sector, new public management, public governance.

Słowa kluczowe: budżet partycypacyjny, partycypacja społeczna, sektor kultury, nowe zarządzanie publiczne, współrządzenie.

\section{Wprowadzenie}

Partycypacja społeczna jest obszarem wpisującym się w dwie koncepcje - nowego zarządzania publicznego (new public management) oraz współzarządzania czy współrządzenia (public governance). Obydwie z wymienionych bazują na decentralizacji 
terytorialnej oraz podziale zadań, kompetencji i źródeł finansowania pomiędzy państwo a jednostki samorządu terytorialnego. Pomijając zalety i wady każdej z koncepcji, szeroko opisane już w literaturze z zakresu zarządzania [zob. m.in. Izdebski 2007], ich istota sprowadza się do implementacji instrumentów (narzędzi, technik i reguł) zarządzania wykorzystywanych w sektorze prywatnym do sektora publicznego w celu poprawy efektywności oraz racjonalności działań w nim podejmowanych. Do takich instrumentów zalicza się najczęściej konsultacje społeczne, ocenę skutków regulacji, partnerstwo publiczno-prywatne i budżet partycypacyjny. Celem artykułu jest przedstawienie ostatniego z wymienionych narzędzi. Poza ogólną charakterystyką tego fenomenu jako formy współdecydowania obywateli o życiu publicznym i rozwoju lokalnym, autorka podejmuje próbę oceny aktywizacji społecznej w obszarach związanych z zaspokajaniem potrzeb kulturowych. Celowi temu służy prezentacja wyników badań budżetów partycypacyjnych 18 miast wojewódzkich w Polsce za lata 2013-2018 oraz wybranych edycji na rok $2019^{1}$. Na podstawie przeprowadzonych badań próbuję odpowiedzieć na pytanie, czy budżet obywatelski jest skutecznym instrumentem partycypacji społecznej w obszarze kultury oraz jaki jest potencjał aktywności środowisk lokalnych zaangażowanych we współzarządzanie sferą publiczną w tym obszarze.

Budżet partycypacyjny jako forma współdecydowania obywateli był już wielokrotnie przedmiotem licznych opracowań na łamach piśmiennictwa fachowego z zakresu rozmaitych dyscyplin (m.in. gospodarki przestrzennej, politologii, socjologii, finansów i zarządzania, urbanistyki). Omawiano go między innymi jako narzędzie public governance [Kołodziej-Hajdo 2017; Owsiak 2016], instrument finansowania inwestycji [Leśniewska-Napierała 2017], środek komunikacji elektronicznej [Matusiak 2016], formę alokacji środków finansowych [Rachwał 2013], mechanizm zrównoważonego rozwoju lokalnego [Sobol 2017a], a wreszcie przejaw współrządzenia [Michalska-Żyła, Brzeziński 2017] czy narzędzie PR jednostek terytorialnych [Ossowski 2017]. Podczas gdy w części artykułów próbowano wskazać ogólne zasady funkcjonowania idei budżetu partycypacyjnego, to jest jego genezę, założenia i dylematy [Pytlik 2017; Polko 2015], w innych ograniczano się do prezentacji lokalnych aspektów jego wdrażania [m.in. Laskowska 2017; Sempiak 2017; Studencka 2017]. Projekty z obszaru kultury obecne w budżetach partycypacyjnych miast wojewódzkich nie były jednak dotąd przedmiotem pogłębionych analiz.

${ }^{1}$ Objęcie analizą wszystkich budżetów miast wojewódzkich na rok 2019 nie było możliwe, ponieważ w większości miast w chwili przygotowywania niniejszego tekstu (koniec września 2018 r.) nie zakończył się jeszcze etap głosowania mieszkańców nad projektami. 


\section{Budzet obywatelski jako przejaw partycypacji spolecznej}

Partycypacja społeczna $\mathrm{z}$ reguły definiowana jest jako współpraca różnych grup obywateli w celu osiągnięcia wspólnych celów (partycypacja horyzontalna) lub współuczestnictwo w procesie podejmowania decyzji z różnymi organami władzy (partycypacja wertykalna). Ten drugi z wymienionych rodzajów partycypacji określany bywa także mianem partycypacji obywatelskiej, bowiem bazuje na pewnego rodzaju umowie społecznej między obywatelami a przedstawicielami władzy samorządowej. Fundamentem tak rozumianej partycypacji jest odpowiedni klimat współpracy, umożliwiający obywatelom realny wpływ na formułowanie polityki publicznej i gwarantujący im możliwość aktywnego udziału w podejmowaniu decyzji odnoszących się do jej realizacji (konsultacje społeczne, udział w głosowaniach itp.).

Jednym z instrumentów partycypacji obywatelskiej jest budżet partycypacyjny (obywatelski). Jego istota polega na: 1) zgłaszaniu przez pojedynczych obywateli oraz grupy interesariuszy propozycji pomysłów inwestycji i zadań, które powinny zostać sfinansowane z części środków budżetu gminy, powiatu lub województwa, a następnie 2) wyborze - w drodze głosowania mieszkańców - tych przedsięwzięć, które powinny zostać zrealizowane.

Wśród cech charakterystycznych odróżniających budżet partycypacyjny od innych praktyk angażujących obywateli wymienić należy:

- prowadzenie publicznej dyskusji między mieszkańcami, którzy rozmawiają z sobą na specjalnie zorganizowanych zebraniach lub na forach;

- skoncentrowanie dyskusji wokół jasno określonych, ograniczonych środków finansowych;

- objęcie mechanizmami finasowania całej gminy, powiatu lub województwa;

- wiążący charakter przeprowadzonych konsultacji (chociaż wynik głosowania nie wiąże organu podejmującego określone działanie, to organ powinien je uzasadnić, gdy podejmuje decyzje wbrew wynikowi konsultacji, a brak takiego uzasadnienia należy traktować jako naruszenie prawa);

- długofalowość i cykliczność (budżety przygotowywane są co roku) [Sempiak 2017: 142].

Mimo podnoszonych w literaturze pewnych wad czy mankamentów budżetu partycypacyjnego (jak choćby niewielka pula środków finansowych w nim przewidziana, wątpliwości co do ustalania zasad zgłaszania i wyboru projektów, łamanie wiążącego charakteru, brak jakichkolwiek regulacji prawnych uniemożliwiających ocenę prawidłowości przeprowadzenia konsultacji) [por. Poniatowicz 2014: 184186], trudno nie dostrzegać jego potencjału. $Z$ pewnością ułatwia on identyfikację potrzeb społeczności lokalnej, wspomaga integrację społeczności wokół ważnych dla niej kwestii oraz podnosi poziom zaufania do władz lokalnych. Na poziomie jednostkowym $z$ kolei daje poczucie przynależności do grupy i pobudza motywację do działania na rzecz dobra wspólnego [Owsiak 2016: 114]. 
Początki budżetu partycypacyjnego sięgają końca lat 80. XX wieku, kiedy ta forma współdecydowania o rozdzielaniu środków publicznych zastosowana została w mieście Porto Alegre w Brazylii. W kolejnych latach zalety płynące z wprowadzenia budżetu partycypacyjnego dostrzegły między innymi Wielka Brytania, Francja, Hiszpania, Włochy, Niemcy czy Kanada [Kowalska 2014: 109; Poniatowicz 2014: 177].

W Polsce pierwszy budżet partycypacyjny uruchomiony został w Sopocie w 2011 roku. Od tego momentu jego mechanizmami zainteresowało się ponad 100 miast.

Warto podkreślić, że w polskim systemie prawnym nie istnieją sztywne przepisy precyzyjnie określające prawne podstawy wdrażania i funkcjonowania budżetów partycypacyjnych. Zachętę do ich wprowadzania stanowią zapisy zawarte w „Ustawie o samorządzie gminnym" [Ustawa $z$ dnia 8 marca 1990 r. o samorzadzie...] oraz Europejskiej Karcie Samorządu Lokalnego [Europejska Karta...]. Wynika z nich, że organy władzy na poszczególnych szczeblach mają możliwość, a nawet obowiązek, prowadzenia konsultacji społecznych z obywatelami (przygotowywanie planów i podejmowanie decyzji) we wszystkich sprawach ich dotyczących [por. Matusiak 2016: 131-134]. W konsekwencji tych zapisów najczęściej podstawą prawną budżetów obywatelskich są stosowne uchwały władz samorządowych (rad miasta, prezydentów, burmistrzów, wójtów, marszałków).

Ponieważ w Polsce nie obowiązuje jeden powszechny model budżetu partycypacyjnego, do budżetów realizowanych przez pojedyncze jednostki samorządu terytorialnego mogą być zgłaszane różnego rodzaju projekty - zarówno te dotyczące budowy, modernizacji lub remontów elementów infrastruktury, jak i te mające na celu poprawę warunków życia i funkcjonowania mieszkańców, a wreszcie dotyczące organizowania wydarzeń o charakterze prospołecznym, kulturalnym, oświatowym lub sportowym.

W większości przypadków każdy mieszkaniec w danej edycji budżetu partycypacyjnego może przygotować i poprzeć więcej niż jeden projekt. Podczas gdy część samorządów wymaga, by osoba zgłaszająca projekt miała ukończony 16. rok życia (np. Toruń), inne dopuszczają zgłoszenia bez względu na wiek (warunkiem jest, że osoby niepełnoletnie muszą posiadać zgodę rodzica lub opiekuna prawnego (np. Warszawa). Do budżetów partycypacyjnych można składać propozycje odnoszące się do zaspokajania potrzeb mieszkańców całego miasta, powiatu, województwa (tzw. projekty duże lub ogólnomiejskie, ogólnopowiatowe, ogólnowojewódzkie) oraz dotyczące rozwiązywania problemów mieszkańców mniejszych obszarów danej jednostki terytorialnej (tzw. projekty małe lub projekty dzielnicowe, osiedlowe). Od 2017 roku w ramach tak zwanego zielonego budżetu obywatelskiego można przygotowywać także projekty tworzenia nowych terenów zieleni lub rewitalizacji istniejących. Aby zgłosić projekt do budżetu obywatelskiego, należy opisać pomysł na specjalnym formularzu, zebrać podpisy poparcia (i ewentualnie dodatkowe materiały wskazane w formularzu), a następnie dostarczyć komplet dokumentów do 
stosownego urzędu. Z reguły przy zgłaszaniu projektów jedynymi ograniczeniami są okres realizacji inwestycji danego przedsięwzięcia, który nie powinien przekraczać jednego roku kalendarzowego, oraz graniczna kwota przewidziana na realizację poszczególnych typów projektów (np. niższa dla projektów dzielnicowych i osiedlowych, wyższa - dla ogólnomiejskich).

Wszystkie zgłoszone do władz lokalnych projekty podlegają analizie formalnej, którą prowadzą wydziały danej jednostki samorządowej lub specjalnie w tym celu powołane zespoły oceniające. Po zakończeniu procesu weryfikacji formalnej ogłaszane są listy projektów, które poddaje się pod głosowanie mieszkańców (drogą tradycyjną - w wyznaczonych do tego punktach konsultacyjnych, lub drogą elektroniczną - za pośrednictwem serwisów WWW). Weryfikacja głosujących odbywa się na podstawie adresu zamieszkania, numeru PESEL i dowodu osobistego. Projekty, które uzyskają największą liczbę głosów, mają największą szansę na realizację w kolejnym roku kalendarzowym ${ }^{2}$.

\section{Budzety partycypacyjne jako przedmiot badan}

Budżety partycypacyjne stanowią interesujący, choć niełatwy przedmiot badań. Mimo że większość jednostek terytorialnych udostępnia materiały dotyczące realizacji kolejnych edycji budżetów, to materiały te są niejednokrotnie niekompletne (brakuje np. informacji o liczbie zgłoszonych projektów, liczbie oddanych głosów) i rozproszone na różnych stronach WWW (np. instytucji obywatelskich, urzędów miasta, serwerach $z$ danymi otwartymi). Innym problemem jest operowanie przez osoby opracowujące dane różnymi jednostkami miar - niekiedy jest to liczba osób, innym razem liczba głosów, jeszcze innym - liczba uzyskanych punktów, a wreszcie frekwencja wyrażona w procentach. Odrębną kwestią jest udostępnianie materiałów $\mathrm{w}$ nieedytowalnych formatach danych oraz brak zestawień sumarycznych pozwalających między innymi na ocenę popularności kategorii tematycznych reprezentowanych przez poszczególne projekty (np. infrastruktura $v s$ kultura $v s$ edukacja). Wszystko to powoduje, że mamy do czynienia z materiałem niezwykle różnorodnym pod względem formy i treści, wymagającym żmudnej i czasochłonnej pracy [zob. też Żelazna-Jochim 2017].

${ }^{2}$ Wyjątkowy na skalę całego kraju sposób przeprowadzania budżetu obywatelskiego wprowadził Gorzów Wielkopolski. Pomysły można zgłaszać tu poprzez standardowe formularze bądź podczas specjalnego spotkania dyskusyjnego, organizowanego w każdej dzielnicy. Na spotkaniu zebrani mogą przyznać rekomendację dla projektów lub, przy jednomyślności, wybrać projekty do realizacji, jednocześnie rezygnując z przeprowadzania głosowania. 


\section{Vetodologia badań}

Ponieważ celem niniejszego artykułu jest udzielenie odpowiedzi na pytanie, czy budżet obywatelski stanowi efektywny instrument partycypacji społecznej w obszarze kultury, poddałam analizie budżety obywatelskie wdrożone w 18 miastach wojewódzkich ${ }^{3}$ w latach 2013-2018 oraz dane z wybranych budżetów na rok 2019. W poszczególnych ich edycjach szczegółową analizą objęto takie zagadnienia, jak liczba projektów realizowanych z obszaru kultury, ich rodzaj, wysokość przyznanych środków finansowych i poziom zaangażowania mieszkańców w ich poparcie wyrażone liczbą oddanych głosów. Jako projekty z obszaru kultury traktowano inicjatywy służące:

1) budowie, modernizacji i rewitalizacji obiektów i instytucji kultury (np. budowa amfiteatrów, modernizacja sal widowiskowych, wyposażenie bibliotek i muzeów, konserwacja zabytków i pomników pamięci);

2) organizacji wydarzeń i imprez artystyczno-kulturalnych (pokazy filmowe i wystawy plenerowe, bookcrossing ${ }^{4}$, koncerty, festyny, zajęcia dydaktyczne, spotkania integracyjne i warsztaty twórcze organizowane dla różnych kategorii odbiorców przez podmioty działające w sektorze kultury).

Z badań wykluczono jedynie te przedsięwzięcia o charakterze prospołecznym, w których opisie formalnym nie podano żadnych informacji o programie kulturalnym (np. festyny parafialne), jak również te, które pozostawiały wątpliwości co do wiodącego charakteru wydarzenia (np. pikniki osiedlowe). Z przyczyn oczywistych badaniami nie objęto także projektów z zakresu kultury fizycznej.

Analiz poszczególnych budżetów partycypacyjnych dokonano na podstawie dokumentów udostępnionych na stronach WWW poszczególnych urzędów miasta oraz pozyskanych $\mathrm{w}$ drodze korespondencji elektronicznej z ich przedstawicielami.

\section{Projekty z obszaru kultury w budzetach partycypacyjnych miast wojewódzkich w latach 2013-2018 oraz wybranych budzetach na rok 2019 - rezultaty badan i dyskusja}

Najwcześniej, bo już w 2013 roku, budżety partycypacyjne wprowadzono w Bydgoszczy, Gorzowie Wielkopolskim, Poznaniu, Wrocławiu i Zielonej Górze. W dziewięciu miastach do współdecydowania o budżecie gminnym mieszkańców zapraszano od

${ }^{3}$ Pod pojęciem „miasta wojewódzkie” należy rozumieć miasta, które od dnia 1 stycznia 1999 r. są siedzibą wojewody i/lub sejmiku województwa.

${ }^{4}$ Pozostawianie książek w miejscach publicznych, jak również w miejscach celowo utworzonych (stoliki, regały, gabloty) po to, by znalazca mógł je przeczytać i przekazać dalej. 
2014 roku, w pozostałych czterech - od roku 2015. W większości przypadków określenie „budżet partycypacyjny na ... rok” oznaczało rok realizacji projektów (głosowanie na projekty odbywało się w roku poprzedzającym realizację). W przypadku Krakowa i Wrocławia w określeniu „budżet partycypacyjny na ... rok” zawarty był natomiast rok głosowania mieszkańców, mimo że głosowanie dotyczyło projektów przewidzianych do realizacji na rok kolejny.

Ogółem w latach 2013-2018 w ramach wszystkich budżetów partycypacyjnych miast wojewódzkich poddano pod głosowanie 23116 projektów, z których do realizacji mieszkańcy wybrali 6329 (27\%). $908 \mathrm{z}$ nich stanowiły projekty z obszaru kultury (14\%) (por. tabela 1).

W momencie przygotowywania niniejszego opracowania (wrzesień 2018 r.) w przypadku większości miast wojewódzkich rozpoczął się etap głosowania na projekty zgłoszone do realizacji na rok 2019. Tym razem na listach znalazło się 5400 propozycji zadań, z tego 488 z obszaru kultury (por. tabela 1). W czterech miastach (Rzeszów, Toruń, Warszawa, Zielona Góra) do końca września 2018 roku etap głosowania zakończono. W jego wyniku do realizacji wybrano 1095 projektów, z czego 257 z obszaru kultury. Tym samym sumaryczna liczba wszystkich projektów z obszaru kultury rekomendowanych do realizacji z budżetów partycypacyjnych wprowadzonych w latach 2013-2019 wyniosła 1165.

Zebrane dane dowodzą, że w dotychczas wdrożonych w miastach wojewódzkich budżetach partycypacyjnych projekty z obszaru kultury stanowiły niewielki odsetek (14\%) wszystkich projektów przewidzianych do realizacji. Mimo że liczba zadań o charakterze kulturowym sukcesywnie wzrasta (zob. wykres 1), wciąż jest niewielka $\mathrm{w}$ porównaniu z pozostałymi kategoriami projektów. Bez wątpienia w analizowanych budżetach partycypacyjnych przeważały zadania dotyczące infrastruktury osiedlowej, między innymi budowy parkingów i zatok postojowych, chodników, zagospodarowania terenów sportowo-rekreacyjnych. Największa liczba projektów z obszaru kultury została natomiast przewidziana do realizacji w roku 2018. Fakt ten nie dziwi, bowiem w tym roku pula środków finansowych przeznaczona na poszczególne budżety była najwyższa (zob. tabela 5). Stosunkowo duża liczba projektów kulturalnych, które otrzymały rekomendację mieszkańców w miastach, gdzie zakończono już głosowanie nad budżetami partycypacyjnymi na rok 2019, pozwala ostrożnie prognozować, że w budżetach na kolejne lata zadań z tego zakresu będzie coraz więcej. 


\begin{tabular}{|c|c|c|c|c|c|c|c|c|c|c|c|c|}
\hline 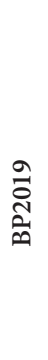 & $\simeq$ & 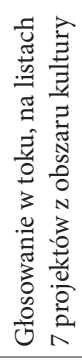 & 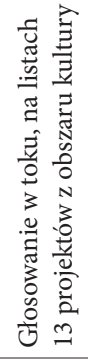 & 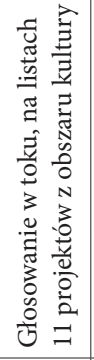 & 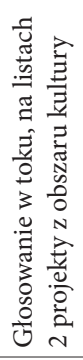 & 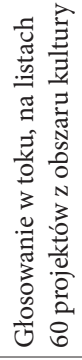 & 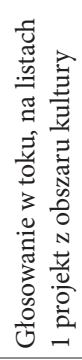 & * & 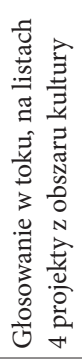 & 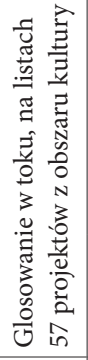 & 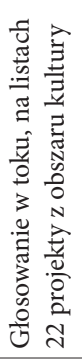 & 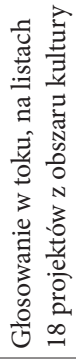 \\
\hline & ט & n & $\stackrel{\infty}{\not}$ & $\stackrel{\vec{m}}{ }$ & if & 学 & \& & & $\stackrel{0}{0}$ & $\widehat{\infty}$ & $\exists$ & ฉ \\
\hline \multirow{3}{*}{$\begin{array}{l}\infty \\
\stackrel{\overbrace{}}{\sim} \\
\stackrel{\infty}{n}\end{array}$} & 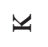 & 0 & - & 0 & 0 & $\hat{m}$ & 0 & $\stackrel{\mathscr{N}}{\sim}$ & 0 & in & 6 & in \\
\hline & $\simeq$ & $\stackrel{\infty}{m}$ & $\tilde{m}$ & $\stackrel{\varrho}{\varrho}$ & f & $\stackrel{\vec{m}}{\overrightarrow{7}}$ & $\ddot{\sim}$ & 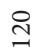 & $\underset{H}{H}$ & $\stackrel{\sim}{\sim}$ & $\widehat{\curvearrowright}$ & $\stackrel{\infty}{-}$ \\
\hline & 0 & $\mathbb{H}$ & $\underset{\mathbb{N}}{\stackrel{+}{N}}$ & సิ & $\stackrel{\text { o }}{ }$ & $\stackrel{\sqrt[N]{\sim}}{\mathrm{N}}$ & $\stackrel{\infty}{+}$ & $\stackrel{\check{F}}{\mathscr{F}}$ & $\stackrel{\infty}{=}$ & 오 & $\stackrel{m}{n}$ & $\underset{\exists}{\stackrel{g}{4}}$ \\
\hline \multirow{3}{*}{ 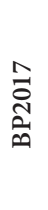 } & 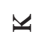 & N & $N$ & $\sim$ & - & r & 0 & $\stackrel{m}{-}$ & - & $\underset{m}{\infty}$ & - & - \\
\hline & $\simeq$ & ঐे & 아 & $\exists$ & $\Xi$ & స్ & $\Xi$ & $\tilde{\alpha}$ & $\stackrel{\sim}{\sim}$ & $\stackrel{\infty}{\sim}$ & $\widehat{\triangleq}$ & $\stackrel{m}{=}$ \\
\hline & $\cup$ & ชิ & $\stackrel{2 n}{\bumpeq}$ & $\stackrel{H}{\mathrm{H}}$ & $\hat{\sigma}$ & $\overrightarrow{\mathfrak{n}}$ & 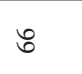 & $\stackrel{\curvearrowright}{m}$ & $\stackrel{9}{f}$ & $\begin{array}{l}\infty \\
\stackrel{\infty}{=} \\
=\end{array}$ & 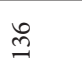 & $\stackrel{\infty}{\sim}$ \\
\hline \multirow{3}{*}{$\begin{array}{l}0 \\
\stackrel{\overbrace{}}{\tilde{I}} \\
\stackrel{\sim}{n}\end{array}$} & $\mathscr{y}$ & in & $N$ & $N$ & 0 & $\stackrel{m}{m}$ & 0 & $a$ & - & $\exists$ & N & $H$ \\
\hline & $\simeq$ & बे & F & $\vec{\lambda}$ & $a$ & $\stackrel{\vartheta}{\exists}$ & $\stackrel{\bullet}{\sim}$ & $\infty$ & $\stackrel{\mathscr{2}}{\sim}$ & $\infty$ & $\hat{\sim}$ & 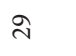 \\
\hline & $\cup$ & in & $\stackrel{\&}{\sharp}$ & $\stackrel{ }{\sim}$ & $\underset{-}{\stackrel{O}{0}}$ & $\underset{\sim}{\sharp}$ & ๙ & 完 & $\begin{array}{l}\stackrel{n}{n} \\
\stackrel{2}{2}\end{array}$ & $\vec{n}$ & ભે & $\exists$ \\
\hline \multirow{3}{*}{$\begin{array}{l}n \\
\stackrel{0}{0} \\
\stackrel{\tilde{n}}{\infty}\end{array}$} & $\check{x}$ & - & - & - & 0 & הี & - & $\vec{\sim}$ & - & in & N & 0 \\
\hline & $\simeq$ & $\stackrel{10}{-1}$ & $\vec{b}$ & $\vec{\sim}$ & $\stackrel{10}{-1}$ & $\infty$ & $\tilde{\sim}$ & $\exists$ & ঐे & $\ddot{b}$ & $\tilde{m}$ & $m$ \\
\hline & 0 & in & ఏ & $\vec{n}$ & $\vec{\Xi}$ & ๙ิ & 8 & $\hat{\mathscr{f}}$ & $\stackrel{\widetilde{v}}{\sim}$ & $\vec{n}$ & $\stackrel{\mathscr{I}}{\sim}$ & ล̄ \\
\hline \multirow{3}{*}{ 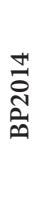 } & $\mathscr{y}$ & - & $\sim$ & - & 0 & 1 & 0 & $\simeq$ & 1 & $n$ & 0 & 1 \\
\hline & $\simeq$ & $\wedge$ & i̊ & $\widehat{\curvearrowright}$ & $\stackrel{\circ}{\circ}$ & 1 & $m$ & $\ddot{b}$ & 1 & f & $\dot{m}$ & 1 \\
\hline & ט & in & $\underset{i}{\stackrel{i}{~}}$ & $\vec{\rho}$ & $\stackrel{1 n}{\wedge}$ & 1 & $\stackrel{\circ}{\circ}$ & 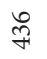 & 1 & 官 & $\stackrel{8}{0}$ & 1 \\
\hline \multirow{3}{*}{$\begin{array}{l}\stackrel{0}{\tilde{N}} \\
\stackrel{\tilde{n}}{\infty}\end{array}$} & $\mathscr{y}$ & 1 & - & 1 & 0 & 1 & 1 & 1 & 1 & 1 & 1 & 1 \\
\hline & $\simeq$ & 1 & $\hat{n}$ & 1 & $\stackrel{\circ}{\sim}$ & 1 & 1 & 1 & 1 & 1 & 1 & 1 \\
\hline & ט & 1 & ப் & 1 & $\stackrel{\infty}{m}$ & 1 & 1 & 1 & 1 & 1 & 1 & 1 \\
\hline 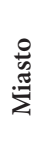 & & 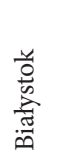 & 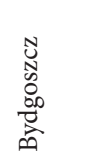 & 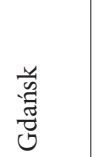 & 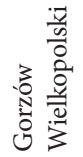 & 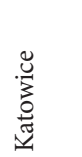 & $\frac{\ddot{U}}{\ddot{\Xi}}$ & 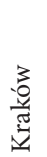 & $\begin{array}{l}\stackrel{\Xi}{3} \\
\end{array}$ & $\begin{array}{l}-10 \\
0 \\
0 \\
-1\end{array}$ & $\begin{array}{l}\underset{N}{E} \\
\text { 嘼 } \\
\end{array}$ & $\begin{array}{l}\stackrel{0}{\circ} \\
\text { مे }\end{array}$ \\
\hline
\end{tabular}




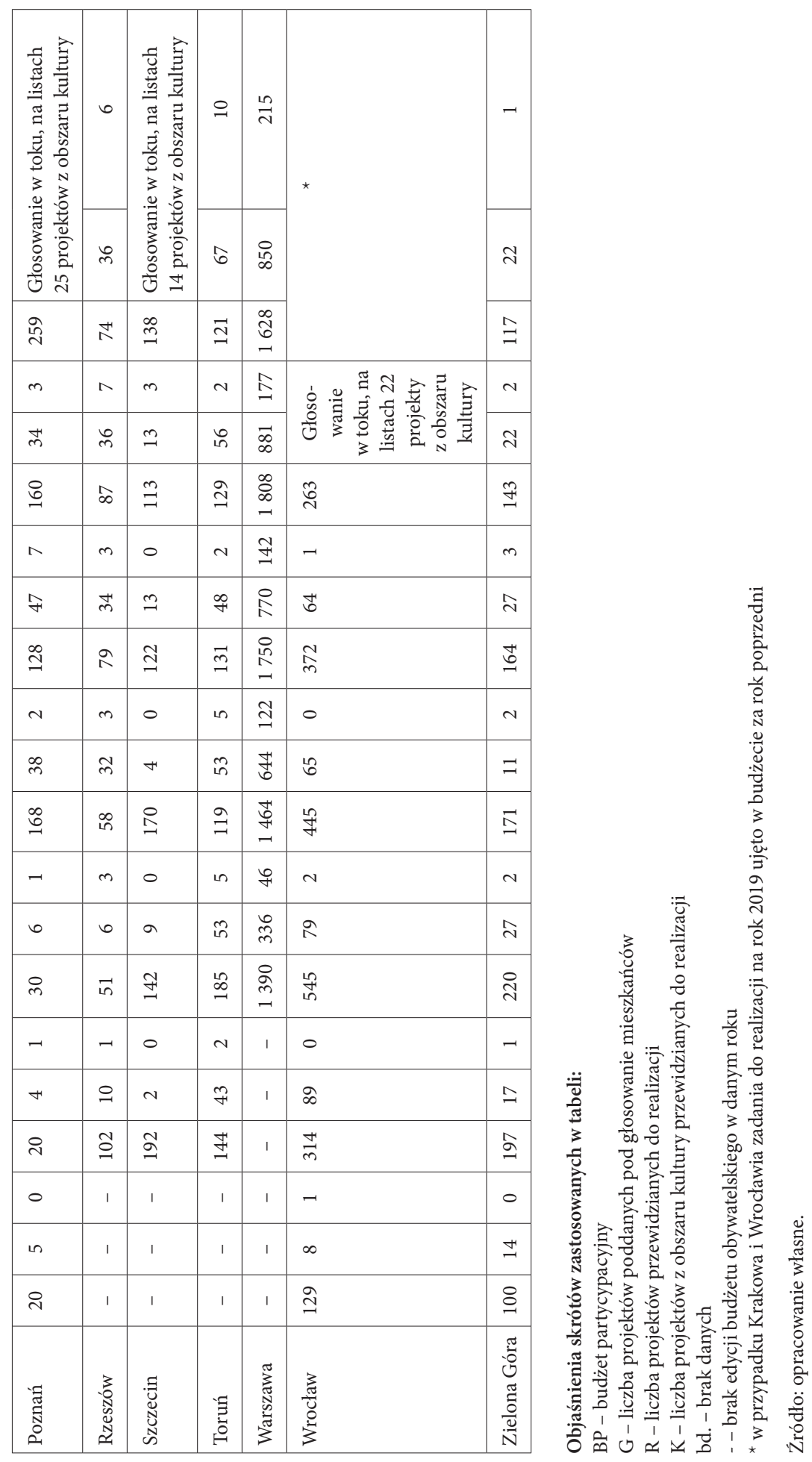




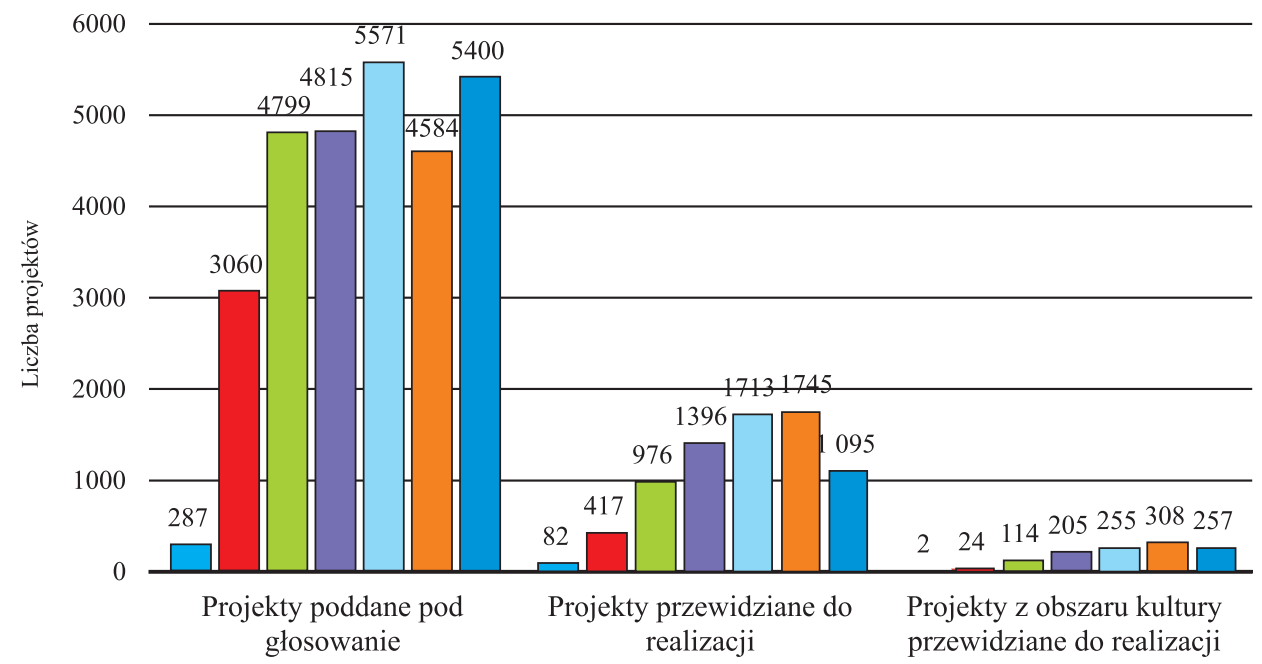

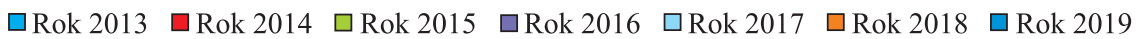

Wykres 1 . Ogólna liczba projektów przewidzianych do realizacji w poszczególnych latach a liczba projektów z obszaru kultury ${ }^{5}$

Źródło: opracowanie własne.

Analiza opisów formalnych 1165 zidentyfikowanych w budżetach partycypacyjnych projektów z obszaru kultury pozwoliła na pogrupowanie projektów w pięć kategorii przedmiotowych, takich jak:

A. budowa nowych obiektów i instytucji kultury (teatry, amfiteatry, kina, sceny plenerowe, sale widowiskowe, książkomaty, biblioteki, muzea);

B. wyposażanie, adaptacja, modernizacja i rewitalizacja obiektów oraz instytucji prowadzących działalność kulturalną (zakup książek i komputerów do bibliotek, wyposażanie sal kinowych, muzeów, pracowni artystycznych, domów kultury, remonty budynków instytucji kultury, renowacja rzeźb, konserwacja zabytków i pomników pamięci);

C. tworzenie artefaktów upowszechniających dziedzictwo artystyczne i kulturalne (murale, trasy zabytkowe, tablice pamiątkowe, rzeźby, fontanny i ławeczki muzyczne);

D. organizacja masowych wydarzeń o charakterze artystyczno-kulturalnym (koncerty, spektakle, festiwale muzyczne, festyny, galerie plenerowe, pokazy filmowe, kabarety, spektakle teatralne);

${ }^{5}$ W analizach za rok 2019 uwzględniono jedynie dane z czterech miast, w których zakończył się etap głosowania. 
E. organizacja zajęć o charakterze artystyczno-kulturalnym odbywających się lub organizowanych przez instytucje prowadzące działalność kulturalną (warsztaty twórcze, plastyczne, muzyczne, spotkania autorskie, spotkania integracyjno-kulturowe, konkursy) (por. tabela 2).

Tabela 2. Projekty z obszaru kultury według wyróżnionych kategorii zadań

\begin{tabular}{|c|c|c|c|c|c|}
\hline \multirow[t]{2}{*}{ Miasto } & \multicolumn{5}{|c|}{$\begin{array}{l}\text { Liczba projektów przewidzianych do realizacji w budżetach partycy- } \\
\text { pacyjnych z lat } 2013-2019^{*} \text { w podziale na kategorie przedmiotowe }\end{array}$} \\
\hline & A & B & $\mathrm{C}$ & $\mathrm{D}$ & $\mathrm{E}$ \\
\hline Białystok & 5 & 2 & 5 & 2 & 1 \\
\hline Bydgoszcz & 2 & 7 & 0 & 0 & 0 \\
\hline Gdańsk & 3 & 2 & 2 & 1 & 4 \\
\hline Gorzów Wielkopolski & 0 & 0 & 0 & 0 & 1 \\
\hline Katowice & 2 & 102 & 1 & 21 & 4 \\
\hline Kielce & 0 & 1 & 0 & 0 & 0 \\
\hline Kraków & 3 & 41 & 7 & 18 & 11 \\
\hline Lublin & 0 & 0 & 1 & 0 & 2 \\
\hline Łódź & 2 & 82 & 5 & 8 & 13 \\
\hline Olsztyn & 0 & 5 & 0 & 6 & 0 \\
\hline Opole & 2 & 1 & 4 & 3 & 0 \\
\hline Poznań & 0 & 5 & 1 & 7 & 1 \\
\hline Rzeszów & 0 & 3 & 1 & 7 & 12 \\
\hline Szczecin & 0 & 0 & 2 & 0 & 1 \\
\hline Toruń & 0 & 8 & 8 & 9 & 1 \\
\hline Warszawa & 23 & 318 & 35 & 147 & 179 \\
\hline Wrocław & 1 & 1 & 1 & 0 & 1 \\
\hline Zielona Góra & 0 & 5 & 3 & 2 & 0 \\
\hline Suma & 43 & 583 & 76 & 231 & 231 \\
\hline
\end{tabular}

* W analizach za rok 2019 uwzglęniono jedynie dane z czterech miast, w których zakończył się etap głosowania. Źródło: opracowanie własne.

Dane z tabeli 2 ilustrują, że w analizowanych budżetach partycypacyjnych największą pod względem liczebnym kategorię projektów stanowiły projekty dotyczące wyposażania, adaptacji, modernizacji i rewitalizacji obiektów oraz instytucji prowadzących działalność kulturalną (50\%). Dominacja tej grupy zdań nie zaskakuje. W obliczu większych lub mniejszych kłopotów finansowych, z jakimi borykają się instytucje 
kultury, cieszy fakt, że mieszkańcy miast wojewódzkich dostrzegają te problemy, zgłaszają propozycje ich rozwiązania, a następnie popierają wdrażanie konkretnych działań poprzez oddanie na nie swojego głosu. Na drugim miejscu ex aequo znalazły się projekty mające na celu organizację masowych wydarzeń kulturalnych oraz projekty zakładające przygotowanie różnego typu zajęć o charakterze artystyczno-kulturalnym (odpowiednio po 19,9\% ogólnej liczby projektów). Ponieważ wśród projektów zgłoszonych w ramach obydwu tych kategorii dominowały propozycje dające możliwość uczestnictwa w bezpłatnych wydarzeniach, a do tego w wielu przypadkach o charakterze integrującym lokalną społeczność, trudno dziwić się ich dużej popularności podczas głosowania. $Z$ zebranych danych wynika, że najmniejszym poparciem mieszkańców miast wojewódzkich cieszyły się z kolei projekty tworzenia artefaktów kulturowych (6,5\% ogólnej liczby projektów) oraz budowy nowych obiektów kultury (3,7\% ogólnej liczby projektów). Można jedynie przypuszczać, że albo przygotowane z tego zakresu propozycje po prostu nie przekonały mieszkańców, albo były one na tyle kosztowne, że ich realizacja mogłaby pochłonąć znaczną część środków przewidzianych w danym budżecie partycypacyjnym. Być możne wynika to także z przeświadczenia, że inwestycje tego typu powinny być pokryte z innych środków finansowych (np. samorządu województwa, powiatu, Ministerstwa Kultury, Banku Gospodarstwa Krajowego).

Bez wątpienia największą liczbę projektów z obszaru kultury rekomendowano do realizacji w Warszawie (702). Na kolejnych pozycjach uplasowały się Katowice (130), Łódź (110) i Kraków (80). Najmniej projektów o charakterze kulturalnym (poniżej 5) zainicjowano z kolei w Gorzowie Wielkopolskim, Kielcach, Lublinie, Szczecinie i Wrocławiu. Dziwi zwłaszcza wynik ostatniego z wymienionych miast, które przecież w 2016 roku otrzymało miano Europejskiej Stolicy Kultury.

Analizując poziom zaangażowania mieszkańców poszczególnych miast wojewódzkich w głosowanie nad projektami zgłoszonymi do budżetów partycypacyjnych, można sformułować wniosek o niewielkiej frekwencji (średnio do $10 \%$ do $28 \%$ ogólnej liczby mieszkańców) oraz malejącym udziale mieszkańców w procesach głosowania na projekty z budżetu partycypacyjnego (por. wykres $3 \mathrm{i}$ tabela 3 ). Jedynie w przypadku Bydgoszczy i Katowic zauważalny jest trend rosnący. W większości miast okres najbardziej wzmożonego zainteresowania inicjatywą budżetu partycypacyjnego przypadł na rok 2015 (7 miast osiągnęło wówczas najwyższą frekwencję). Stosunkowo dużym powodzeniem cieszyły się także pierwsze edycje budżetów partycypacyjnych, z lat 2013 i 2014 (po 3 miasta odnotowały w tych latach większą liczbę osób głosujących). Wypowiedzi mieszkańców, zamieszczane na stronach WWW poszczególnych edycji budżetów partycypacyjnych, wskazują, że na malejące zainteresowanie tą formą partycypacji społecznej mają wpływ: uboga oferta i niska jakość zgłaszanych projektów, upolitycznienie procesu głosowania przez lokalne ugrupowania (lobbing), niedogodne terminy głosowania na projekty (przypadające $\mathrm{z}$ reguły w okresie wakacyjnym), problem $\mathrm{z}$ umiejętnym rozdysponowaniem kwot na poszczególne rodzaje zadań, niechęć do samego procesu głosowania (zwłaszcza 
gdy we wcześniejszych edycjach do realizacji wybrane zostały inne projekty niż te, na które oddało się głos), coraz częściej ujawniane nieprawidłowości związane z organizacją poprzednich edycji budżetów, przedłużające się okresy realizacji zadań $\mathrm{z}$ lat minionych, spowszednienie samej idei budżetu partycypacyjnego, jego „słaba" promocja, a nawet brak wiedzy na jego temat. Podobne argumenty wysuwane są także w literaturze przedmiotu, gdzie dodatkowo przywołuje się takie powody, jak brak wiedzy władz lokalnych na temat realnych problemów społeczności i bezrefleksyjne wdrażanie budżetu partycypacyjnego, nie do końca przemyślany i niekiedy przypadkowy podział środków, poczucie marginalizowania opinii mieszkańców, przekonanie o z góry ustalonych wynikach głosowania, utrata zaufania do przedstawicieli administracji samorządowej, a nawet obawa przed byciem wyśmianym z powodu zaangażowania w proces współdecydowania [Pytlik 2017: 120-121; Zawadzka-Pąk, Lotko 2017: 450; Poniatowicz 2014: 184-186].

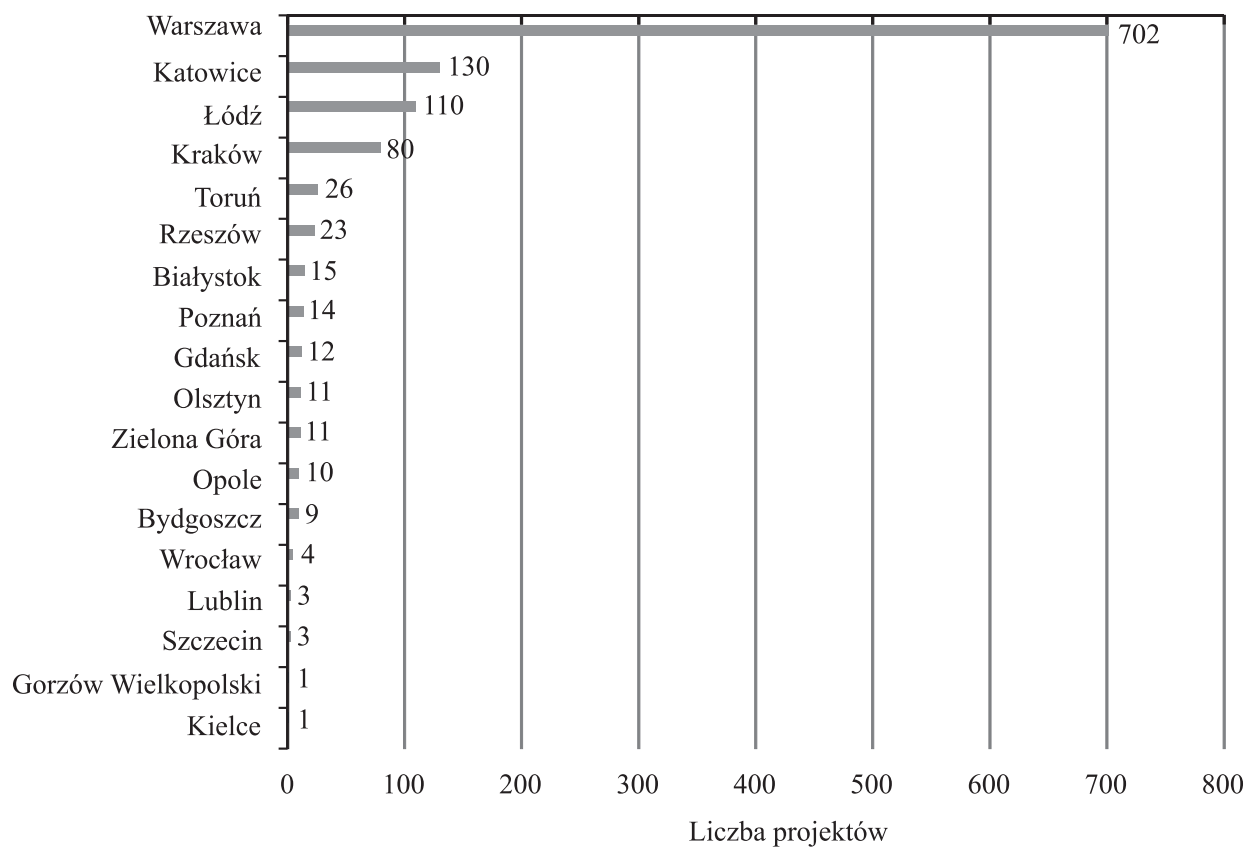

Wykres 2. Sumaryczna liczba projektów z obszaru kultury przewidziana do realizacji w budżetach partycypacyjnych poszczególnych miast wojewódzkich w latach 2013-20196

Źródło: opracowanie własne.

${ }^{6}$ W analizach za rok 2019 uwzględniono jedynie dane z czterech miast, w których zakończył się etap głosowania. 


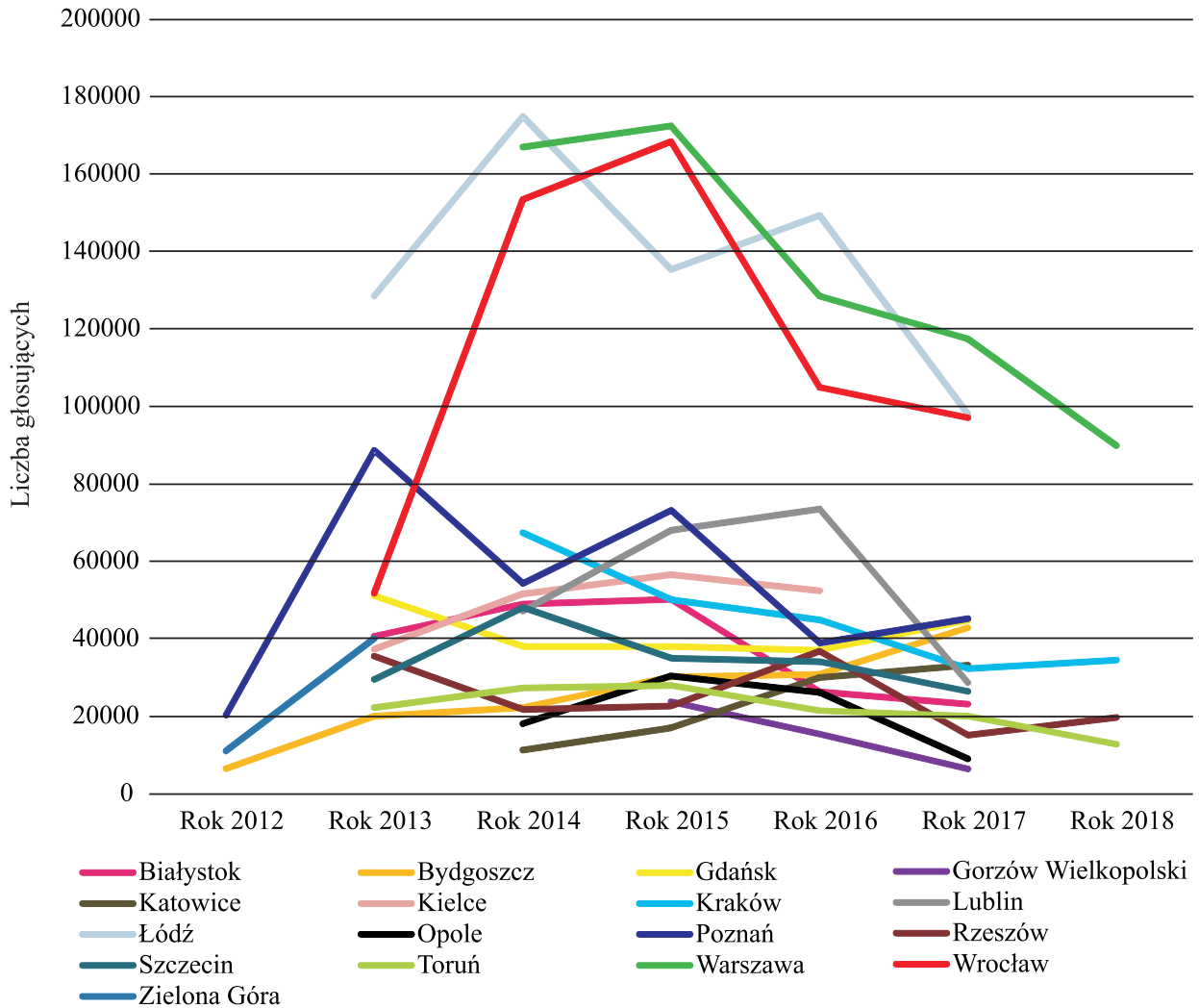

Wykres 3. Frekwencja w poszczególnych edycjach budżetów partycypacyjnych ${ }^{7}$

Źródło: opracowanie własne.

Jak już zauważono, z propozycji zgłoszonych do budżetów partycypacyjnych miast wojewódzkich w latach 2013-2018 do realizacji najczęściej wybierane były zadania dotyczące infrastruktury osiedlowej, bowiem to na te projekty głosowała największa liczba mieszkańców. Liczba głosów oddanych na projekty z obszaru kultury była zdecydowanie mniejsza. Bez pogłębionych analiz motywacji mieszkańców trudno dociekać przyczyn takiego stanu rzeczy. Można jedynie przypuszczać, że albo mieszkańcy zdecydowali się głosować na projekty zabezpieczające ich podstawowe potrzeby, albo oferta projektów z obszaru kultury oceniona została przez nich jako uboga bądź nieinteresująca. Być może zabrakło także skutecznej promocji

7 Ze względu na brak danych dotyczących liczby głosujących, na wykresie nie uwzględniono budżetów partycypacyjnych realizowanych w Olsztynie. 


\begin{tabular}{|c|c|c|c|c|c|c|c|c|c|c|c|c|}
\hline \multirow{7}{*}{ 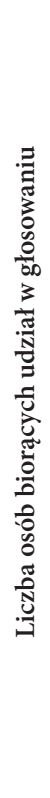 } & 규 & تं & تृं & تृ่ & تृं & تृ் & تृं & $\begin{array}{l}\text { Fै } \\
\text { Hै }\end{array}$ & ठ் & تृ் & $\overrightarrow{0}$ & ப் \\
\hline & $\hat{\text { సे }}$ & $\begin{array}{l}\stackrel{+}{n} \\
\stackrel{\sim}{n}\end{array}$ & 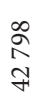 & 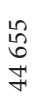 & $\begin{array}{l}\text { ț } \\
\text { రి }\end{array}$ & $\frac{\infty}{\stackrel{\infty}{m}}$ & تृं & $\begin{array}{l}\stackrel{\text { }}{\text { N }} \\
\text { }\end{array}$ & $\begin{array}{l}N \\
\hat{b} \\
\infty \\
\tilde{n}\end{array}$ & $\begin{array}{l}\text { t } \\
\text { م } \\
\text { م }\end{array}$ & ت் & $\begin{array}{l}\infty \\
\stackrel{\infty}{\infty} \\
\infty\end{array}$ \\
\hline & $\stackrel{0}{\stackrel{0}{\sim}}$ & $\begin{array}{l}\text { } \\
\text { ñ } \\
\stackrel{\sim}{0}\end{array}$ & $\begin{array}{l}\circ \\
2 \\
0 \\
0\end{array}$ & 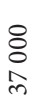 & $\begin{array}{l}\text { 우 } \\
\text { in }\end{array}$ & $\begin{array}{l}0 \\
0 \\
0 \\
0 \\
0\end{array}$ & $\begin{array}{l}\vec{F} \\
\bar{F} \\
\text { in }\end{array}$ & \begin{tabular}{l}
2 \\
$\infty$ \\
\multirow{f}{*}{}
\end{tabular} & $\begin{array}{l}\hat{b} \\
\hat{1} \\
\hat{n}\end{array}$ & 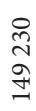 & تृ & $\begin{array}{l}\stackrel{\sigma}{\exists} \\
\stackrel{\sim}{1}\end{array}$ \\
\hline & $\frac{10}{8}$ & $\begin{array}{l}\bar{a} \\
\text { in }\end{array}$ & $\begin{array}{l}\vec{b} \\
-1 \\
0\end{array}$ & $\begin{array}{l}\stackrel{8}{8} \\
\infty \\
\infty\end{array}$ & $\begin{array}{l}0 \\
\hat{b} \\
\stackrel{\sim}{1}\end{array}$ & $\begin{array}{l}\stackrel{0}{8} \\
8 \\
\end{array}$ & $\begin{array}{l}\bar{\infty} \\
10 \\
0 \\
0\end{array}$ & $\begin{array}{l}\vec{b} \\
\text { in }\end{array}$ & 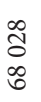 & 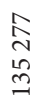 & $\overrightarrow{0}$ & $\begin{array}{l}\overrightarrow{0} \\
\text { } \\
\infty \\
\infty\end{array}$ \\
\hline & $\underset{\sim}{\mathbb{N}}$ & $\begin{array}{l}\stackrel{0}{2} \\
2 \\
\infty\end{array}$ & $\begin{array}{l}\underset{\sim}{\mathbb{N}} \\
\underset{\sim}{N}\end{array}$ & $\begin{array}{l}n \\
\text { مू } \\
\text { ஸे }\end{array}$ & تृ் & $\begin{array}{l}\stackrel{\circ}{N} \\
=\end{array}$ & $\begin{array}{l}\stackrel{0}{n} \\
i n \\
\text { nn }\end{array}$ & 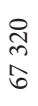 & $\begin{array}{l}\stackrel{2}{7} \\
\text { f }\end{array}$ & \begin{tabular}{l}
+ \\
$\infty$ \\
+ \\
\multirow{-}{*}{}
\end{tabular} & $\overrightarrow{0}$ & 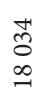 \\
\hline & $\stackrel{m}{\stackrel{n}{\sim}}$ & $\begin{array}{l}\text { ô } \\
\text { 1n } \\
\text { 우 }\end{array}$ & $\begin{array}{l}\text { రิ } \\
\text { రิ }\end{array}$ & $\begin{array}{l}\infty \\
\text { o } \\
\text { in }\end{array}$ & تृं & ' & $\begin{array}{l}\stackrel{0}{N} \\
N \\
\infty\end{array}$ & 1 & 1 & 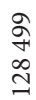 & تृ் & 1 \\
\hline & $\stackrel{\widetilde{N}}{\stackrel{\sim}{*}}$ & 1 & त् & 1 & $\underset{\underset{+}{F}}{\stackrel{\partial}{7}}$ & 1 & 1 & I & 1 & I & 1 & 1 \\
\hline \multirow{7}{*}{ 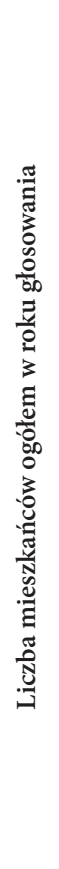 } & $\stackrel{\infty}{\stackrel{\infty}{\sim}}$ & $\begin{array}{l}\infty \\
\stackrel{\infty}{N} \\
\stackrel{N}{\hat{N}}\end{array}$ & $\begin{array}{l}m \\
m \\
\stackrel{m}{n} \\
m\end{array}$ & $\begin{array}{l}\text { 㫕 } \\
\text { से } \\
\text { ț }\end{array}$ & 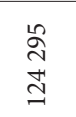 & 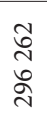 & 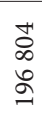 & $\begin{array}{l}\stackrel{\infty}{~} \\
\stackrel{N}{\circ} \\
\end{array}$ & $\begin{array}{l}\text { டे } \\
\infty \\
\text { ले } \\
m\end{array}$ & $\begin{array}{l}\text { İ } \\
\text { \& } \\
\text { \& }\end{array}$ & $\begin{array}{l}\text { R } \\
0 \\
\text { ㅇ } \\
=\end{array}$ & 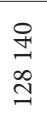 \\
\hline & $\hat{\stackrel{\sim}{~}}$ & $\begin{array}{l}\infty \\
\infty \\
\stackrel{2}{N} \\
\hat{ָ}\end{array}$ & $\begin{array}{l}m \\
m \\
\stackrel{n}{n} \\
m\end{array}$ & 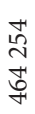 & 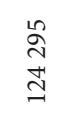 & 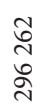 & $\begin{array}{l}\text { ¿ } \\
\infty \\
\circ \\
\circ\end{array}$ & 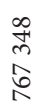 & $\begin{array}{l}\text { ठn } \\
\infty \\
\text { ले } \\
\text { mे }\end{array}$ & $\begin{array}{l}\text { Iิ } \\
\text { \& } \\
\text { వิ }\end{array}$ & $\begin{array}{l}\stackrel{R}{0} \\
\text { I } \\
\end{array}$ & $\begin{array}{l}\stackrel{\text { q }}{1} \\
\stackrel{\infty}{త}\end{array}$ \\
\hline & 윰 & $\begin{array}{l}\stackrel{0}{0} \\
\text { } \\
\stackrel{0}{\circ}\end{array}$ & $\begin{array}{l}\infty \\
m \\
m \\
m\end{array}$ & $\begin{array}{l}\text { 婴 } \\
\hat{n} \\
\text { f }\end{array}$ & 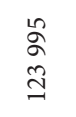 & $\begin{array}{l}\exists \\
\exists \\
\stackrel{\sim}{\beth}\end{array}$ & 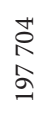 & 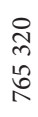 & $\begin{array}{l}8 \\
\stackrel{0}{1} \\
\text { 웅 }\end{array}$ & 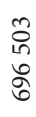 & $\begin{array}{l}2 \\
\Omega \\
\Sigma\end{array}$ & $\begin{array}{l}\underset{N}{N} \\
\infty \\
\Xi\end{array}$ \\
\hline & $\stackrel{n}{\tilde{n}}$ & 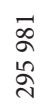 & 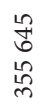 & 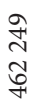 & 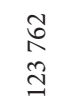 & $\begin{array}{l}\stackrel{\circ}{\alpha} \\
\text { बे }\end{array}$ & $\begin{array}{l}0 \\
0 \\
\infty \\
\infty \\
2\end{array}$ & $\begin{array}{l}\stackrel{8}{\circ} \\
\frac{0}{\circ}\end{array}$ & $\begin{array}{l}\hat{N} \\
\text { 市 } \\
\text { re }\end{array}$ & $\begin{array}{l}\text { مू } \\
\text { ஓे }\end{array}$ & 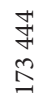 & $\begin{array}{l}\vec{\aleph} \\
\infty \\
=\end{array}$ \\
\hline & $\stackrel{\Delta}{\vec{N}}$ & $\begin{array}{l}\text { aे } \\
\stackrel{a}{\alpha} \\
\text { an }\end{array}$ & $\begin{array}{l}\sqrt{0} \\
0 \\
\hat{n} \\
n\end{array}$ & $\begin{array}{l}\stackrel{2}{\infty} \\
\stackrel{+}{+} \\
\stackrel{+}{+}\end{array}$ & $\begin{array}{l}\stackrel{\mathscr{Z}}{ \pm} \\
\underset{J}{J}\end{array}$ & $\begin{array}{l}N_{0} \\
\infty \\
D_{\infty}\end{array}$ & $\begin{array}{l}\hat{1} \\
\infty \\
\infty \\
2\end{array}$ & $\begin{array}{c}\stackrel{\infty}{\infty} \\
\vec{b}\end{array}$ & $\begin{array}{l}\mathbb{N} \\
\vec{m}\end{array}$ & $\begin{array}{l}+ \\
8 \\
\varnothing \\
\varnothing\end{array}$ & $\begin{array}{l}\vec{\infty} \\
\infty \\
\cong \\
\end{array}$ & $\begin{array}{l}\stackrel{H}{\hat{N}} \\
\stackrel{2}{\exists}\end{array}$ \\
\hline & $\stackrel{m}{\pi}$ & 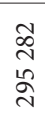 & 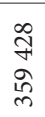 & $\begin{array}{l}\bar{m} \\
\text { in } \\
\vec{t}\end{array}$ & $\begin{array}{l}\stackrel{H}{H} \\
\stackrel{N}{+} \\
\underset{J}{+}\end{array}$ & 1 & $\begin{array}{l}\stackrel{1}{1} \\
\infty \\
2\end{array}$ & 1 & 1 & $\begin{array}{l}\stackrel{m}{\sim} \\
\vec{\nabla}\end{array}$ & \begin{tabular}{l}
$\stackrel{1}{0}$ \\
$\hat{\sigma}$ \\
\multirow{1}{\pm}{} \\
$=$
\end{tabular} & 1 \\
\hline & $\stackrel{N}{3}$ & 1 & $\begin{array}{l}\vec{n} \\
\stackrel{+}{n} \\
\vec{n}\end{array}$ & I & $\begin{array}{l}\text { Oे } \\
\text { D } \\
\text { త్ }\end{array}$ & 1 & 1 & I & 1 & I & 1 & 1 \\
\hline \multicolumn{2}{|c|}{ 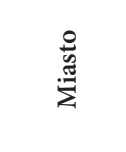 } & $\frac{n}{0}$ & 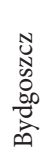 & 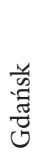 & 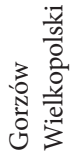 & 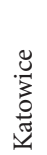 & $\frac{\tilde{u}}{\tilde{g}}$ & $\begin{array}{l}\text { 总 } \\
\text { 苟 }\end{array}$ & $\begin{array}{l}\Xi \\
3 \\
3\end{array}$ & 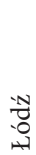 & $\begin{array}{l}\text { E } \\
\text { N } \\
\text { D. } \\
0\end{array}$ & $\begin{array}{l}\stackrel{0}{\circ} \\
\text { ̊े }\end{array}$ \\
\hline
\end{tabular}




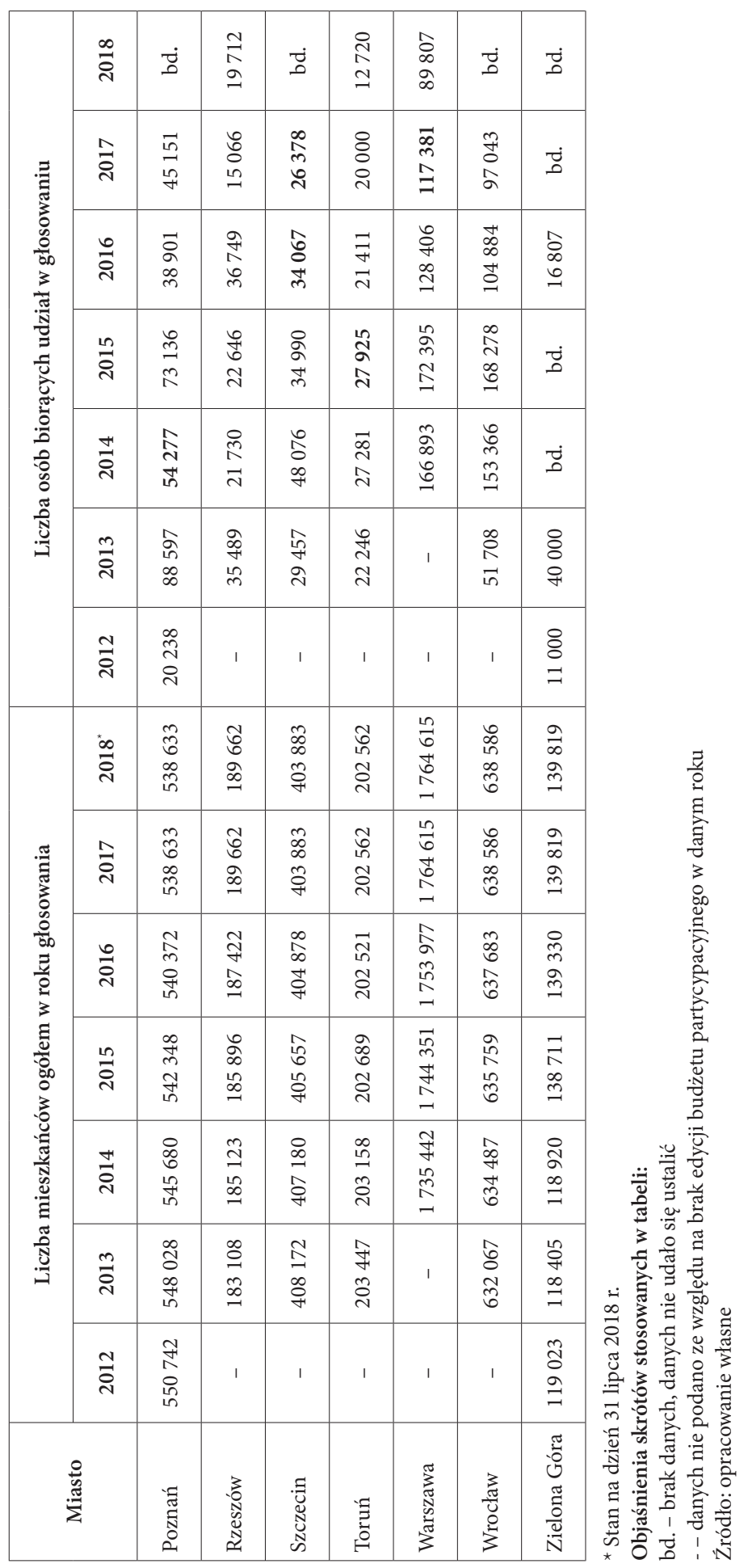




\begin{tabular}{|c|c|c|c|c|c|c|c|c|c|c|c|c|c|c|c|c|c|c|c|}
\hline 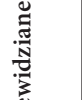 & 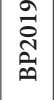 & ت्ठ & تं & تें & تें & تే & ت் & 1 & تृ் & تृ் & ت் & ت் & تृ் & $\begin{array}{l}\infty \\
\infty \\
\infty \\
\text { in }\end{array}$ & تृं & $\overrightarrow{\tilde{O}}$ & $\begin{array}{l}\stackrel{m}{\infty} \\
\infty \\
\stackrel{-}{-}\end{array}$ & 1 & $\tilde{\widehat{\delta}}$ \\
\hline 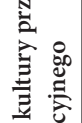 & 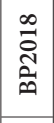 & $\underset{\infty}{\tilde{m}}$ & fี & 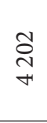 & 1 & 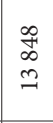 & 1 & $\begin{array}{l}\tilde{\Omega} \\
\alpha \\
\infty \\
-1\end{array}$ & 1 & $\begin{array}{l}\overrightarrow{\hat{O}} \\
\text { ลे }\end{array}$ & $\stackrel{\vec{n}}{\hat{0}}$ & 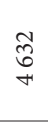 & $\begin{array}{l}\infty \\
\stackrel{\infty}{7} \\
m\end{array}$ & $\underset{\underset{\sim}{\tilde{H}}}{+}$ & & $\underset{\exists}{\exists}$ & 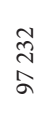 & تే & 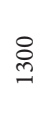 \\
\hline 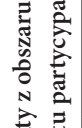 & 空 & $\begin{array}{l}\vec{\infty} \\
\stackrel{-}{-}\end{array}$ & 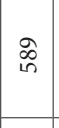 & $\begin{array}{l}\text { 足 } \\
\text { in } \\
-1\end{array}$ & ๙ి & 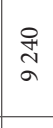 & 1 & $\begin{array}{l}\frac{1}{6} \\
\therefore\end{array}$ & 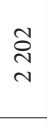 & $\begin{array}{l}\stackrel{\vec{m}}{\sim} \\
\stackrel{\sim}{v}\end{array}$ & 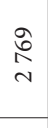 & 吕 & $\begin{array}{l}\infty \\
\infty \\
0 \\
+\end{array}$ & 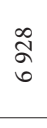 & 1 & $\underset{N}{\stackrel{D}{N}}$ & $\begin{array}{l}\stackrel{9}{-1} \\
\stackrel{0}{0}\end{array}$ & के & $\begin{array}{l}\stackrel{0}{\infty} \\
\infty \\
+\end{array}$ \\
\hline 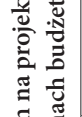 & 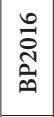 & 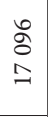 & $\overrightarrow{0}$ & $\begin{array}{l}\stackrel{0}{\infty} \\
\infty \\
\sim\end{array}$ & 1 & $\begin{array}{l}\vec{\infty} \\
\stackrel{N}{n}\end{array}$ & 1 & $\begin{array}{l}\text { के } \\
\text { aे }\end{array}$ & $\begin{array}{l}l \\
\stackrel{2}{0} \\
+\end{array}$ & 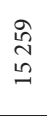 & $\stackrel{0}{\sim}$ & $\begin{array}{l}\stackrel{2}{\curvearrowright} \\
\sim\end{array}$ & $\begin{array}{l}\infty \\
\stackrel{\infty}{\circ} \\
+\end{array}$ & 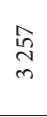 & 1 & $\hat{\sigma}$ & $\begin{array}{l}\stackrel{2}{o} \\
\stackrel{+}{\circ} \\
\infty\end{array}$ & 1 & $\begin{array}{l}\stackrel{n}{n} \\
\stackrel{n}{\sim}\end{array}$ \\
\hline 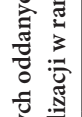 & 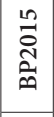 & $\stackrel{n}{\stackrel{n}{n}}$ & in & $\underset{-1}{:}$ & 1 & $\overrightarrow{8}$ & గ్ & $\begin{array}{l}\text { నे } \\
\text { مे }\end{array}$ & $\stackrel{\circlearrowright}{\stackrel{0}{\leftrightarrows}}$ & $\frac{\sqrt{n}}{6}$ & $\underset{\infty}{\overrightarrow{0}}$ & 1 & $\begin{array}{c}\hat{\sim} \\
\sigma\end{array}$ & 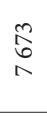 & 1 & $\underset{\substack{P \\
\text { N } \\
\sim}}{ }$ & 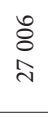 & $\begin{array}{l}\vec{\sigma} \\
\sim\end{array}$ & 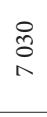 \\
\hline 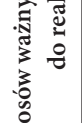 & 总 & $\begin{array}{l}2 \\
\text { o } \\
\text { in }\end{array}$ & تं & $\underset{\sim}{\mathscr{J}}$ & 1 & 1 & 1 & $\begin{array}{l}\hat{0} \\
0 \\
0 \\
i n\end{array}$ & 1 & gે & 1 & 1 & $\begin{array}{l}\text { aे } \\
\text { בิ }\end{array}$ & $\begin{array}{l}\stackrel{\circ}{\infty} \\
\stackrel{m}{m}\end{array}$ & 1 & Oे & 1 & 1 & $\stackrel{H}{\stackrel{H}{2}}$ \\
\hline 步 & $\mid \begin{array}{c}m \\
\stackrel{n}{n} \\
\stackrel{n}{n}\end{array}$ & 1 & ت் & 1 & 1 & 1 & 1 & 1 & 1 & 1 & 1 & 1 & 1 & 1 & 1 & 1 & 1 & $\begin{array}{l}H_{0} \\
\infty \\
-1\end{array}$ & 1 \\
\hline & 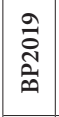 & ت் & تं & ت் & تُ & تُ & ت் & 1 & تृ் & تृ் & تृ่ & تే & ت் & $\begin{array}{l}\vec{I} \\
\stackrel{A}{f}\end{array}$ & تే & $\begin{array}{l}\vec{\infty} \\
\infty \\
\infty \\
\infty\end{array}$ & $\begin{array}{l}\infty \\
\infty \\
\infty \\
\infty \\
\infty\end{array}$ & 1 & $\begin{array}{l}n \\
\hat{i} \\
0 \\
0\end{array}$ \\
\hline 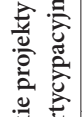 & 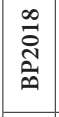 & $\begin{array}{l}\stackrel{\infty}{\stackrel{\sim}{二}} \\
\vec{\sim}\end{array}$ & 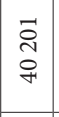 & 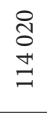 & $\begin{array}{c}\stackrel{n}{n} \\
\text { in } \\
\text { in }\end{array}$ & 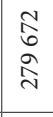 & $\begin{array}{l}\stackrel{+}{J} \\
\stackrel{J}{J}\end{array}$ & $\begin{array}{l}\circ \\
\stackrel{+}{7} \\
2 \\
\text { లి }\end{array}$ & 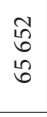 & $\begin{array}{l}\stackrel{n}{0} \\
m \\
m \\
F\end{array}$ & $\begin{array}{l}\text { I } \\
\stackrel{+}{a} \\
\text { + }\end{array}$ & 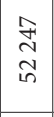 & 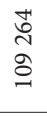 & 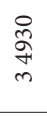 & 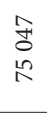 & $\begin{array}{l}8 \\
8 \\
\text { in }\end{array}$ & 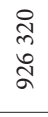 & "ृ் & $\begin{array}{l}\vec{n} \\
\stackrel{0}{\infty} \\
\infty\end{array}$ \\
\hline 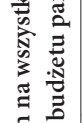 & 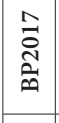 & $\begin{array}{l}\underset{\sigma}{\sigma} \\
\underset{\sim}{\sim}\end{array}$ & $\mid \begin{array}{l}\stackrel{0}{1} \\
\text { N } \\
\text { הి }\end{array}$ & 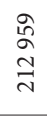 & $\begin{array}{l}\qquad 0 \\
8 \\
0\end{array}$ & $\begin{array}{l}\overrightarrow{\tilde{n}} \\
\stackrel{2}{2} \\
\stackrel{n}{a}\end{array}$ & $\begin{array}{l}\text { ఫิ } \\
\text { I } \\
\text { in }\end{array}$ & $\begin{array}{l}\infty \\
\stackrel{8}{0} \\
\vec{n} \\
m\end{array}$ & $\begin{array}{l}\omega \\
\infty \\
\infty \\
\widehat{\Omega} \\
\end{array}$ & $\begin{array}{l}8 \\
\infty \\
\vec{b}\end{array}$ & $\begin{array}{l}\hat{\infty} \\
0 \\
\stackrel{0}{a} \\
i\end{array}$ & $\mid \begin{array}{l}a \\
\infty \\
\infty \\
\infty \\
\infty\end{array}$ & 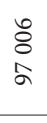 & $\underset{\infty}{\tilde{\infty}}$ & 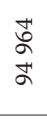 & $\begin{array}{l}\vec{\infty} \\
m \\
\overrightarrow{0}\end{array}$ & $\begin{array}{l}\vec{m} \\
\infty \\
\infty\end{array}$ & $\begin{array}{l}\hat{\alpha} \\
\hat{\alpha} \\
\text { స్ }\end{array}$ & $\begin{array}{l}\text { ₹ै } \\
\infty \\
\text { nn }\end{array}$ \\
\hline 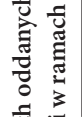 & 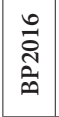 & $\begin{array}{l}\hat{O} \\
\dot{O} \\
\dot{H}\end{array}$ & $\begin{array}{l}\hat{q} \\
\vec{N} \\
\vec{N}\end{array}$ & $\begin{array}{l}0 \\
6 \\
2 \\
2\end{array}$ & $\begin{array}{l}\hat{\widehat{N}} \\
\vec{\sim}\end{array}$ & $\begin{array}{l}0 \\
0 \\
\infty \\
\infty \\
\infty\end{array}$ & 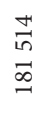 & 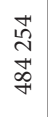 & $\begin{array}{l}\text { बे } \\
\text { హे }\end{array}$ & 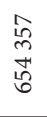 & \begin{tabular}{l}
\multirow{0}{0}{} \\
$\exists$
\end{tabular} & 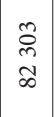 & $\begin{array}{l}\infty \\
i \\
i \\
\infty \\
i \\
\sim\end{array}$ & $\begin{array}{l}\vec{\infty} \\
\stackrel{+}{+}\end{array}$ & 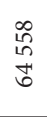 & $\begin{array}{l}\stackrel{2}{2} \\
\hat{b} \\
\swarrow 0\end{array}$ & $\begin{array}{l}\infty \\
\infty \\
\infty \\
0 \\
0 \\
-1\end{array}$ & $\begin{array}{l}\stackrel{N}{\Omega} \\
\stackrel{n}{N}\end{array}$ & 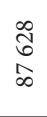 \\
\hline 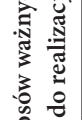 & $\begin{array}{l}n \\
\stackrel{n}{\tilde{N}} \\
\stackrel{n}{\oplus}\end{array}$ & $\begin{array}{l}\overrightarrow{0} \\
\overrightarrow{0} \\
\stackrel{m}{m}\end{array}$ & $\begin{array}{l}\overrightarrow{5} \\
\Lambda \\
\vdots\end{array}$ & 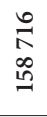 & $\begin{array}{l}\text { 吕 } \\
\text { o } \\
\text { f }\end{array}$ & $\begin{array}{l}9 \\
\infty \\
\infty \\
0 \\
-1\end{array}$ & $\begin{array}{l}\vec{F} \\
\infty \\
\searrow \\
\Xi\end{array}$ & 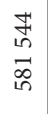 & 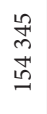 & 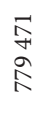 & $\begin{array}{l}\tilde{\infty} \\
\infty \\
\tilde{N}\end{array}$ & $\begin{array}{l}\infty \\
\infty \\
\infty \\
m\end{array}$ & $\begin{array}{l}\overrightarrow{2} \\
\hat{2} \\
0\end{array}$ & $\begin{array}{l}\hat{F} \\
\vec{m}\end{array}$ & $\begin{array}{l}\text { तี } \\
\infty \\
\infty\end{array}$ & 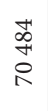 & $\begin{array}{l}\stackrel{\circ}{i n} \\
\stackrel{i}{n}\end{array}$ & $\begin{array}{l}\tilde{n} \\
\hat{\delta} \\
\infty \\
0 \\
0 \\
0\end{array}$ & $\begin{array}{l}\stackrel{8}{9} \\
\stackrel{1}{I}\end{array}$ \\
\hline 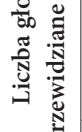 & 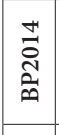 & ت्ठ & تृ & $\begin{array}{l}\vec{\Xi} \\
\stackrel{2}{\infty} \\
\stackrel{+}{+}\end{array}$ & 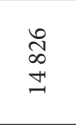 & 1 & ت் & 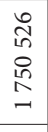 & 1 & 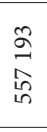 & $\begin{array}{l}\stackrel{0}{10} \\
0\end{array}$ & 1 & 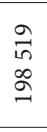 & $\begin{array}{l}\infty \\
\infty \\
\infty \\
\infty \\
m\end{array}$ & $\stackrel{\infty}{\stackrel{\infty}{1}}$ & 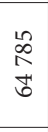 & 1 & 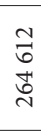 & $\begin{array}{l}\hat{n} \\
\hat{2} \\
\stackrel{0}{\infty}\end{array}$ \\
\hline & 离 & 1 & تं & 1 & $\underset{\infty}{\mathbb{N}}$ & 1 & 1 & 1 & 1 & 1 & 1 & 1 & $\begin{array}{l}\overrightarrow{0} \\
\stackrel{n}{6} \\
\overrightarrow{0}\end{array}$ & 1 & 1 & 1 & 1 & $\begin{array}{l}\stackrel{\infty}{\beth} \\
\stackrel{\Xi}{\Xi}\end{array}$ & $\begin{array}{l}\stackrel{\infty}{\circ} \\
\stackrel{f}{f}\end{array}$ \\
\hline 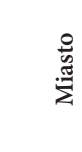 & & 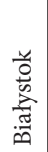 & 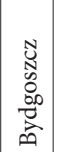 & 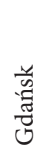 & 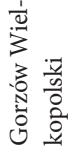 & 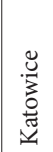 & $\frac{\ddot{U}}{\widetilde{\Xi}}$ & 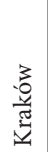 & $\begin{array}{l}\stackrel{\Xi}{\exists} \\
\stackrel{3}{\Xi}\end{array}$ & 式 & 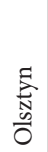 & 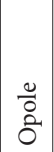 & 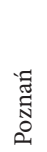 & 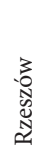 & $\begin{array}{l}\text { ज्ञ } \\
\tilde{J} \\
\text { N }\end{array}$ & 艼 & 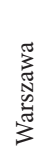 & 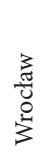 & 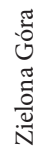 \\
\hline
\end{tabular}




\begin{tabular}{|c|c|c|c|c|c|c|c|c|c|c|c|c|c|c|c|c|c|c|c|}
\hline 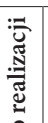 & 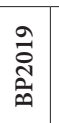 & ت் & $\overrightarrow{0}$ & ப் & ப் & $\overrightarrow{0}$ & ப் & 1 & $\overrightarrow{0}$ & ت் & ت் & ت் & ப் & $\begin{array}{l}8 \\
8 \\
8 \\
\&\end{array}$ & ப் & 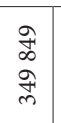 & $\begin{array}{l}\frac{1 n}{n} \\
i n \\
\overrightarrow{1} \\
i n \\
m\end{array}$ & 1 & \begin{tabular}{l}
8 \\
8 \\
0 \\
$\infty$ \\
\hdashline
\end{tabular} \\
\hline 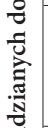 & 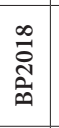 & $\begin{array}{l}\stackrel{1}{ } \\
\infty \\
\sim \\
\tilde{N} \\
\sim\end{array}$ & $\begin{array}{l}8 \\
8 \\
\circ \\
\stackrel{1}{1}\end{array}$ & $\begin{array}{l}8 \\
8 \\
2 \\
\frac{2}{q}\end{array}$ & 1 & $\begin{array}{l}8 \\
8 \\
\tilde{1} \\
0 \\
-1\end{array}$ & 1 & 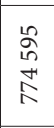 & 1 & 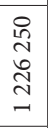 & 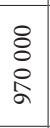 & $\begin{array}{l}8 \\
\vdots \\
\circ \\
i n\end{array}$ & 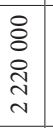 & 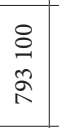 & $\begin{array}{l}\stackrel{8}{0} \\
0 \\
\infty \\
\infty \\
m\end{array}$ & $\left|\begin{array}{l}0 \\
0 \\
0 \\
0 \\
0\end{array}\right|$ & $\begin{array}{l}\stackrel{2}{1} \\
\stackrel{1}{O} \\
\stackrel{H}{\sim} \\
i n\end{array}$ & $\vec{D}$ & $\begin{array}{l}8 \\
8 \\
8 \\
8 \\
+1\end{array}$ \\
\hline 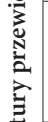 & $\begin{array}{l}\stackrel{0}{\vec{D}} \\
\stackrel{\sim}{\infty}\end{array}$ & 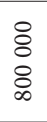 & $\begin{array}{l}8 \\
8 \\
0 \\
0\end{array}$ & $\begin{array}{l}8 \\
8 \\
0 \\
\stackrel{0}{n}\end{array}$ & $\begin{array}{l}\stackrel{8}{\circ} \\
\infty\end{array}$ & $\begin{array}{l}8 \\
8 \\
m \\
= \\
=\end{array}$ & 1 & 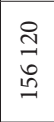 & $\begin{array}{l}8 \\
8 \\
8 \\
8\end{array}$ & $\begin{array}{l}\stackrel{8}{2} \\
\stackrel{m}{2} \\
\stackrel{f}{f} \\
-\end{array}$ & $\begin{array}{l}8 \\
\vdots \\
0 \\
8 \\
0\end{array}$ & 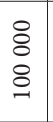 & 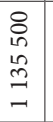 & $\begin{array}{l}8 \\
8 \\
\pm \\
=\end{array}$ & 1 & \begin{tabular}{l|} 
\\
8 \\
0 \\
$n$ \\
$m$
\end{tabular} & \begin{tabular}{l|} 
\\
\\
$\infty$ \\
$\infty$ \\
-1 \\
$\infty$ \\
+ \\
+
\end{tabular} & $\begin{array}{l}8 \\
8 \\
\circ \\
\stackrel{1}{n}\end{array}$ & \begin{tabular}{|l|} 
\\
8 \\
8 \\
$\vdots$ \\
$\vdots$ \\
\end{tabular} \\
\hline 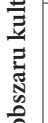 & $\begin{array}{l}\stackrel{0}{\stackrel{N}{N}} \\
\stackrel{\sim}{\infty}\end{array}$ & 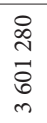 & \begin{tabular}{l} 
ूे \\
\multirow{+}{*}{}
\end{tabular} & 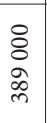 & 1 & 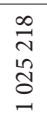 & 1 & $\begin{array}{l}\stackrel{8}{0} \\
i \\
\stackrel{1}{N} \\
\end{array}$ & $\begin{array}{l}8 \\
\stackrel{0}{ } \\
10 \\
\mathbb{Z} \\
+1\end{array}$ & 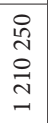 & 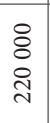 & $\begin{array}{l}8 \\
\vdots \\
\vdots \\
\vdots\end{array}$ & 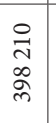 & $\begin{array}{l}8 \\
i n \\
\exists \\
=\end{array}$ & 1 & $\begin{array}{l}\vec{B} \\
\tilde{n} \\
\tilde{f} \\
+\end{array}$ & 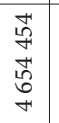 & 1 & $\begin{array}{l}8 \\
0 \\
\infty \\
2\end{array}$ \\
\hline $\begin{array}{l}0 \\
\frac{0}{0} \\
\frac{3}{0} \\
\frac{0}{0} \\
0\end{array}$ & 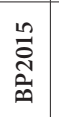 & $\begin{array}{l}8 \\
8 \\
8 \\
\stackrel{10}{+} \\
-1\end{array}$ & $\begin{array}{l}\stackrel{2}{2} \\
\infty \\
\widehat{్}\end{array}$ & $\begin{array}{l}\stackrel{2}{2} \\
f \\
\text { I } \\
F\end{array}$ & 1 & $\begin{array}{l}\stackrel{0}{n} \\
\hat{n} \\
\infty \\
m \\
m\end{array}$ & 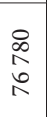 & 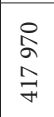 & $\begin{array}{l}8 \\
8 \\
\infty \\
\infty\end{array}$ & 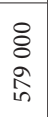 & $\begin{array}{l}8 \\
0 \\
\infty \\
=\end{array}$ & 1 & 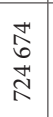 & $\begin{array}{l}8 \\
8 \\
\circ \\
\infty \\
\text { in } \\
\end{array}$ & 1 & 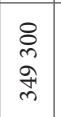 & $\begin{array}{l}\stackrel{0}{a} \\
\infty \\
\hat{N} \\
\stackrel{1}{-1}\end{array}$ & 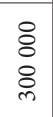 & $\begin{array}{l}8 \\
8 \\
8 \\
i n \\
\\
-1\end{array}$ \\
\hline 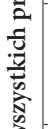 & 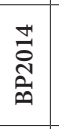 & \begin{tabular}{l}
8 \\
8 \\
8 \\
$\&$ \\
\hdashline
\end{tabular} & $\begin{array}{l}\hat{\delta} \\
i n \\
n \\
m\end{array}$ & 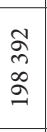 & 1 & 1 & 1 & $\mid \begin{array}{l}\infty \\
\infty \\
\tilde{N} \\
\tilde{N}\end{array}$ & 1 & $\begin{array}{l}8 \\
\stackrel{+}{0} \\
\text { 品 }\end{array}$ & 1 & 1 & $\begin{array}{l}8 \\
\vdots \\
0 \\
\vdots \\
\sim\end{array}$ & $\begin{array}{l}8 \\
8 \\
8 \\
0\end{array}$ & 1 & $\begin{array}{l}8 \\
8 \\
0 \\
8 \\
0\end{array}$ & 1 & 1 & $\begin{array}{l}0 \\
8 \\
0 \\
0\end{array}$ \\
\hline 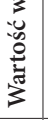 & 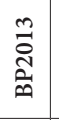 & 1 & $\begin{array}{l}\stackrel{\infty}{\sim} \\
\vec{\sim}\end{array}$ & 1 & 1 & 1 & 1 & 1 & 1 & 1 & ' & 1 & 1 & 1 & 1 & 1 & 1 & $\begin{array}{l}8 \\
8 \\
\& \\
\circ\end{array}$ & 1 \\
\hline & 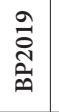 & $\stackrel{\circ}{\circ}$ & 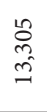 & $\begin{array}{l}\stackrel{\partial}{\infty} \\
\stackrel{-}{\approx}\end{array}$ & $\begin{array}{l}\infty \\
\stackrel{\infty}{6} \\
\overrightarrow{0}\end{array}$ & $\begin{array}{l}\infty \\
\hat{i}\end{array}$ & in & 1 & $\stackrel{2}{\sim}$ & 아 & 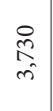 & $\stackrel{m}{*}$ & ¿े & 12 & $a$ & $\begin{array}{l}0 \\
0 \\
0 \\
\end{array}$ & ثै & 1 & 0 \\
\hline 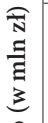 & 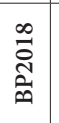 & $\stackrel{ }{ }$ & $\stackrel{ }{ }$ & $\exists$ & 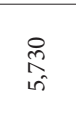 & $\stackrel{\sim}{\sim}$ & in & $\begin{array}{l}\text { 孚 } \\
\hat{I}\end{array}$ & $\stackrel{2}{\sim}$ & or & 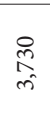 & $\begin{array}{l}\hat{L n} \\
\hat{i}\end{array}$ & $\stackrel{\infty}{\stackrel{1}{2}}$ & 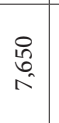 & $\infty$ & $\begin{array}{l}0 \\
h_{0}^{2} \\
n^{n}\end{array}$ & $\stackrel{10}{\overrightarrow{6}}$ & $\begin{array}{l}\text { 今 } \\
\text { ñ } \\
\text { und }\end{array}$ & 0 \\
\hline 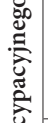 & 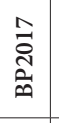 & $n$ & in & 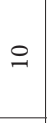 & $\begin{array}{l}\stackrel{0}{0} \\
\stackrel{\leftrightarrow}{f}\end{array}$ & i & $\begin{array}{l}\stackrel{2}{2} \\
\hat{2} \\
i n\end{array}$ & $\frac{\mathscr{P}}{\stackrel{+}{I}}$ & $\stackrel{20}{\sim}$ & q & 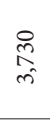 & $\begin{array}{l}\hat{n} \\
\hat{i}\end{array}$ & $\stackrel{12}{\cong}$ & $\begin{array}{l}8 \\
6 \\
0 \\
N^{2}\end{array}$ & $\wedge$ & 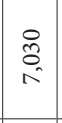 & in & $\stackrel{\mathscr{n}}{\sim}$ & 0 \\
\hline 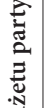 & 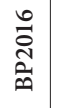 & i & in & $\stackrel{ }{1}$ & $\sim$ & ¿ి & 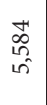 & $\begin{array}{l}n \\
2 \\
0 \\
0 \\
0 \\
=\end{array}$ & $\stackrel{2}{\sim}$ & o f & $\begin{array}{c}\stackrel{n}{n} \\
\text { nn }\end{array}$ & $\begin{array}{l}\hat{n} \\
\hat{i}\end{array}$ & $\stackrel{2}{\sim}$ & 12 & 0 & $\begin{array}{l}0 \\
0 \\
0\end{array}$ & $\begin{array}{l}\stackrel{\ln }{\vec{N}} \\
\underset{n}{n}\end{array}$ & $\stackrel{\stackrel{n}{\sim}}{ }$ & 0 \\
\hline 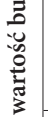 & 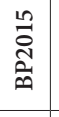 & $\approx$ & in & $\Rightarrow$ & $N$ & $\stackrel{ }{ }$ & $\begin{array}{l}8 \\
\stackrel{9}{+2} \\
\text { in }\end{array}$ & $\Xi$ & 으 & o t & $\stackrel{m}{m}$ & $\sim$ & $\circ$ & $\mathfrak{L n}^{10}$ & in & $\mid \begin{array}{l}0 \\
0 \\
0 \\
0 \\
0\end{array}$ & $\begin{array}{l}\hat{\tilde{N}} \\
\hat{\sigma} \\
\hat{N}\end{array}$ & ¿ & 0 \\
\hline 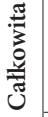 & 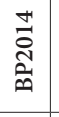 & $\stackrel{\circ}{\circ}$ & in & $\begin{array}{l}\stackrel{R}{2} \\
\text { aे }\end{array}$ & $N$ & 1 & $\begin{array}{l}0 \\
\text { 응 } \\
\text { in }\end{array}$ & $\stackrel{\ln }{f}$ & 1 & 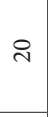 & $\underset{\substack{n \\
\hat{N}}}{2}$ & 1 & 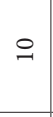 & in & in & 栾 & 1 & ¿ & 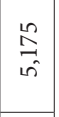 \\
\hline & $\begin{array}{l}\stackrel{m}{\vec{D}} \\
\stackrel{\sim}{m}\end{array}$ & 1 & in & 1 & - & 1 & 1 & 1 & 1 & 1 & 1 & 1 & $\stackrel{ }{1}$ & 1 & 1 & 1 & 1 & $m$ & $m$ \\
\hline 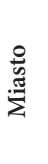 & & 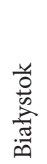 & 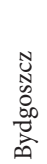 & 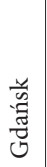 & 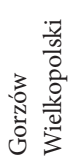 & 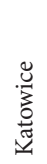 & $\frac{\tilde{u}}{\tilde{v}}$ & 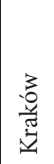 & $\begin{array}{l}\frac{\Xi}{0} \\
\frac{3}{3}\end{array}$ & 资 & 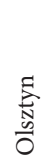 & 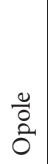 & 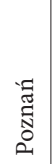 & 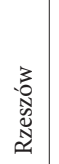 & 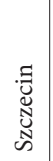 & 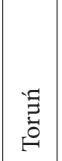 & 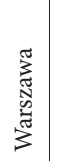 & 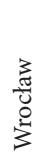 & 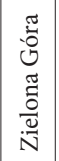 \\
\hline
\end{tabular}


tego rodzaju inicjatyw. Najwięcej głosów (ogółem 197 770) na projekty z obszaru kultury oddano w budżecie obywatelskim z 2018 roku (w 8 miastach odnotowano wówczas najwyższy poziom zainteresowania tego rodzaju projektami). Stanowiło to jednak i tak zaledwie 7\% ogólnej liczby wszystkich zebranych głosów. Stosunkowo dużą popularnością cieszyły się także projekty kulturalne zaproponowane w budżetach na lata 2016 i 2017 (por. tabela 4). Zwiększone zainteresowanie projektami z obszaru kultury w ostatnich trzech latach może być skutkiem przygotowywania lepszych propozycji z tego zakresu lub/i dowodzić rozbudzania czy podnoszenia świadomości kulturalnej mieszkańców.

Analiza wartości środków finansowanych przewidzianych do rozdysponowania w ramach budżetów partycypacyjnych wskazuje w większości miast wojewódzkich na systematyczne zwiększanie nakładów na cel. Wzrost ten nie przekłada się jednak na zwiększony poziom finansowania przedsięwzięć z obszaru kultury. Ponieważ projekty z tego zakresu należą do mniejszości, konsekwencją tego jest także wydatkowanie na nie mniejszej puli środków (por. tabela 5).

Jak ilustrują powyższe dane, w latach 2013-2018 ogółem z budżetów partycypacyjnych na projekty z zakresu kultury przeznaczono zaledwie około $61 \mathrm{mln}$ zł (z prawie 1,2 mld zł łącznej wartości wszystkich edycji budżetów partycypacyjnych). Największe nakłady na ten cel poniesiono z budżetów na rok 2018 (ogółem ponad $17 \mathrm{mln}$ zł), a najmniejsze na rok 2013 (ok. 700 tys. zł). W ramach wszystkich edycji budżetów obywatelskich $z$ lat 2013-2018 najwięcej środków finansowych na projekty z obszaru kultury wydatkowano w Warszawie (łącznie ok. $16 \mathrm{mln}$ zł) oraz w Białymstoku (łącznie ok. $10 \mathrm{mln}$ zł), a najmniej w Kielcach (niecałe 80 tys. zł).

\section{Podsumowanie}

Partycypacja społeczna może dziś przybierać rozmaite formy, od produkcji partnerskiej, poprzez wikinomię i crowdsourcing, aż po budżet partycypacyjny. Ostatni z wymienionych, gdy jest wdrażany w sposób przemyślany i uwzględniający potrzeby społeczności lokalnej, może przekładać się na poprawę usług świadczonych przez władze miejskie, sprzyjać integracji społecznej i większej identyfikacji mieszkańców z miejscem zamieszkania oraz wpływać na podnoszenie poziomu lokalnej kultury politycznej [Pytlik 2017: 120].

Przeprowadzona analiza wykorzystania budżetu partycypacyjnego w zarządzaniu publicznym w 18 miastach wojewódzkich nie przynosi satysfakcjonujących rezultatów, jeśli chodzi o sektor kultury. Niewielka liczba projektów z tego obszaru wybranych do realizacji w poszczególnych edycjach budżetu (14\% wszystkich projektów z lat 2013-2018), małe zaangażowanie mieszkańców w proces głosowania nad zadaniami z tego zakresu (nieprzekraczające 7\% wszystkich oddanych głosów), a wreszcie niewielkie środki finansowe przeznaczone na ten cel (ok. 5\% łącznej 
wartości wszystkich budżetów partycypacyjnych w latach 2013-2018) nie pozwalają uznać budżetu partycypacyjnego za skuteczne narzędzie służące wzmacnianiu aktywnego udziału obywateli w życiu kulturalnym. Mimo że mechanizmy budżetu obywatelskiego stwarzają możliwość do podejmowania rozmaitych eksperymentów z partycypacją społeczną, działań na rzecz rozwoju widowni czy otwierania nowych przestrzeni dla rozwoju uczestnictwa w kulturze i edukacji kulturowej, badania dowodzą, że potencjał tego narzędzia nie jest do końca wykorzystany. Poza argumentami przytoczonymi w niniejszym opracowaniu, by odpowiedzieć na pytanie o przyczyny takiego stanu rzeczy, konieczne byłoby przeprowadzenie pogłębionych analiz motywacji zarówno instytucji kultury, które nie uczestniczą w przygotowywaniu projektów do budżetów partycypacyjnych, jak i „,autorów” projektów do nich zgłaszanych. Uzasadniona byłaby także weryfikacja form promocji projektów kulturowych w budżetach partycypacyjnych, a wreszcie zbadanie potrzeb kulturalnych mieszkańców oraz kierunku ich rozwoju.

\section{Bibliografia}

Europejska Karta Samorząu Terytorialnego, sporządzona w Strasburgu dnia 15 października 1985 r. (1994), Dz. U. nr 124 poz. 607.

Izdebski H. (2007), Od administracji publicznej do public governance, „Zarządzanie Publiczne”, nr 1, s. 7-20.

Kołodziej-Hajdo M. (2017), Budżet partycypacyjny jako instrument zarzadzania publicznego w koncepcji public governance na przykładzie miasta Krakowa, „Studia Ekonomiczne, t. 341, s. 159-170.

Kowalska I. (2014), Partycypacja społeczna w kształtowaniu budżetu jednostki samorzadu terytorialnego - budżet partycypacyjny, „Economics and Management, nr 4, s. 108-122.

Korolewska M., Marchewka-Bartkowiak K. (2015), Budżet obywatelski jako przejaw aktywności społecznej - analiza doświadczeń na przykładzie jednostek samorząu terytorialnego, „Studia BAS”, nr 4 (44): „Obywatelstwo i społeczeństwo obywatelskie w Polsce”, s. 123-140.

Laskowska E. (2017), Budżet partycypacyjny i jego rola na przykładzie miasta stołecznego Warszawy, ,Zeszyty Naukowe SGGW w Warszawie. Polityki Europejskie, Finanse i Marketing”, nr 18 (67), s. 73-85.

Leśniewska-Napierała K. (2017), Budżet partycypacyjny jako narzędzie finansowania inwestycji $w$ Łodzi, „Studia Miejskie”, nr 25, s. 107-119.

Matusiak J. (2016), Elektroniczne budżety obywatelskie w największych miastach Polski, „Studia Prawa Publicznego", nr 1 (13), s. 129-147.

Michalska-Żyła A., Brzeziński K. (2017), Budżet partycypacyjny jako mechanizm wspótrządzenia miastem, „Annales Universitatis Mariae Curie-Skłodowska, sectio K - Politologia”, t. $24 \mathrm{nr} 2$, s. $205-223$. 
Ossowski S. (2017), Budżet obywatelski jako forma partycypacji mieszkańców czy narzędzie PR urzędu? Przykład Poznańskiego Budżetu Obywatelskiego, „Przegląd Politologiczny”, nr 4, s. 145-158.

Owsiak K. (2016), Wykorzystanie wybranych narzędzi public governance przez jednostki samorzadu terytorialnego w Polsce a wzrost partycypacji społecznej, „Studia Ekonomiczne”, t. 294, s. 109-120.

Partycypacja obywatelska, https://partycypacjaobywatelska.pl/ [odczyt: 30.09.2018].

Polko A. (2015), Models of Participatory Budgeting - the Case Study of Polish City, „Journal of Economics \& Management", vol. 19, s. 34-44.

Poniatowicz M. (2014), Kontrowersje wokół idei budżetu partycypacyjnego jako instrumentu finansów lokalnych, „Studia Ekonomiczne”, t. 198, cz. 1, s. 177-188.

Potocki A. (2017), Zależność samorządowych instytucji kultury w aspektach prawnoadministracyjnych, „Przegląd Prawno-Ekonomiczny”, nr 40, s. 198-213.

Pytlik B. (2017), Budżet partycypacyjny w Polsce. Ewolucja i dylematy, „Studia z Polityki Publicznej", nr 1, s. 103-122.

Rachwał M. (2013), Budżet partycypacyjny jako nowa forma współdecydowania o finansach lokalnych, „Przegląd Politologiczny”, nr 3, s. 173-185.

Sempiak A. (2017), Budżet obywatelski, jako instrument partycypacji społecznej w mieście Jelenia Góra, „Prace Naukowe Wyższej Szkoły Zarządzania i Przedsiębiorczości z siedzibą w Wałbrzychu", t. 40, nr 1, s. 139-152.

Sobol A. (2017a), Budżet obywatelski jako narzędzie rozwoju lokalnego, „Studia Ekonomiczne, t. 316, s. 172-182.

Sobol A. (2017b), Mieszkaniec jako konsument i wspóttwórca oferty miejskiej, „Studia Ekonomiczne", t. 326, s. 138-148.

Studencka K. (2017), Budżet obywatelski w Katowicach i jego konsekwencje w przestrzennym zagospodarowaniu miasta, „Budownictwo i Architektura”, t. 16 nr 2, s. 81-88.

Ustawa z dnia 8 marca 1990 r. o samorzadzie gminnym (1990), Dz.U. nr 16 poz. 95.

Zawadzka-Pąk U.K., Lotko E. (2017), Motywacja mieszkańców polskich samorządów do angażowania się w proces budżetowania partycypacyjnego, „Prace Naukowe Uniwersytetu Ekonomicznego we Wrocławiu”, nr 478: „Finanse i rachunkowość na rzecz zrównoważonego rozwoju - edukacja, etyka, innowacje. Finanse", s. 444-454.

Żelazna-Jochim D. (2017), Idea partycypacji społecznej a ocena informacji publikowanych na stronach internetowych wybranych urzędów z województwa łódzkiego, „Przegląd Nauk Ekonomicznych", nr 27, s. 211-225. 